\title{
Airmass Trajectories and Long Range Transport of Pollutants: Review of Wet Deposition Scenario in South Asia
}

\author{
Umesh Kulshrestha and Bablu Kumar \\ School of Environmental Sciences, Jawaharlal Nehru University, New Delhi 110067, India \\ Correspondence should be addressed to Umesh Kulshrestha; umeshkulshrestha@gmail.com
}

Received 24 April 2014; Revised 6 June 2014; Accepted 9 June 2014; Published 12 August 2014

Academic Editor: M. Ángeles García

Copyright (C) 2014 U. Kulshrestha and B. Kumar. This is an open access article distributed under the Creative Commons Attribution License, which permits unrestricted use, distribution, and reproduction in any medium, provided the original work is properly cited.

\begin{abstract}
This paper presents a review of airmass trajectories and their role in air pollution transport. It describes the concept, history, and basic calculation of air trajectories citing various trajectory models used worldwide. It highlights various areas of trajectory applications and errors associated with trajectory calculations. South Asian region receives airmasses from Europe, Middle East, Africa, and Indian Ocean, and so forth, depending upon the season. These airmasses are responsible for export and import of pollutants depositing in nearby states. Trajectory analysis revealed that soil is contributed by the dust storms coming from Oman through Gulf and Iran, while most of black carbon (BC) sources are located in India. A detailed review of trajectories associated with wet deposition events indicated that airmasses coming from Europe and Middle East carry high concentration of acidic pollutants which are deposited in Himalayan ranges. Similarly, trajectory analysis revealed that acidic pollutants from continental anthropogenic sources are transported to an ecosensitive site in Western Ghats in India and the outward fluxes of anthropogenic activities of Indo-Gangetic region are transported towards Bay of Bengal. Hence, transboundary and long range transport of pollutants are very important issues in South Asia which need immediate attention of scientists and policy makers.
\end{abstract}

\section{Introduction}

1.1. Concept of Trajectories. Air flow may be described in two different ways: (i) Eulerian (named after Swiss mathematician Leonhard Euler) and (ii) Lagrangian (named after French mathematician J L Lagrange) [1-3]. In the Eulerian approach, the air flows through the points fixed in the space whereas in the Lagrangian approach [3], individual air parcel is chosen and followed as it moves in time and space. Most of chemistry models are based on Eulerian approach as this is a useful tool to explain various chemical and physical processes. In the Eulerian model, chemical reactions are calculated based on the concentration of a pollutant diluted over the entire grid scale. Most of transport and dispersion models use Lagrangian approach due to some limitations in Eulerian model, for example, boundary layer in top entrainment and convective transport, and so forth $[4,5]$. The advantage of Lagrangian approach is that it has minimum numerical diffusion [5]. Airmass trajectory is calculated to show the pathway of an infinitesimally air parcel through a centerline of an advected airmass having vertical and horizontal dispersion.
Tracing of the pathway followed by an air parcel upwind from the selected coordinates is termed as "backward air trajectory," while calculation of best possible pathway to be followed downwind from the selected coordinates in due course of time is called "forward trajectory." The calculation of backward air trajectory using Lagrangian approach is easier and computationally cheap as it excludes the influence of upwind on the receptor site. Lagrangian approach has also been applied in photochemical modeling $[6,7]$.

1.2. History of Air Trajectories. Trajectories were first computed by Petterssen in 1940 which were based upon graphic representation [8]. But with the advancement of computer in 1960s, people started isentropic analysis, trajectory calculations, and their graphic representation on computers [9]. Since then, trajectory calculations and their presentation have experienced gradual advancement in techniques and technologies. Trajectory calculations gained more importance when Rodhe plotted airmass trajectories and established that acid rain occurrence in Northern Europe was mainly due 
to industrial sources located in the south and west [10]. In air pollution science, Fox and Ludwick also reported one of the pioneering studies using backward air trajectories which identified the source region of pollution [11]. Ashbaugh and coworkers used air trajectories for identifying the sources of sulphur [12]. They also used these trajectories to predict the airmass history and corresponding high levels of sulphates.

In due course of time, different workers started looking into various aspects of trajectory calculations such as errors, accuracy of calculation, and multiple presentations. Polissar and coworkers addressed various issues related to trajectory calculation such as vertical transport, phenomenon of subgrid scale, convection, turbulences, and uncertainties about meteorological data [13]. Stohl and Fleming and coworkers have reported a comprehensive review of back trajectories $[14,15]$. At present, the trajectories are more accurate with $3 \mathrm{D}$ presentation having several other computer driven features [16]. Simulations of multiple trajectories are also possible now. The advantage of multiple trajectories is that these provide measure of uncertainty in the pathways of airmass transport [17]. However, calculated trajectories always have some uncertainty and hence user should know the magnitude of such errors while interpreting the results. Assumptions regarding vertical transport, sparse meteorological data, numerical inaccuracies during computation, subgrid scale phenomenon, turbulence, convection, evaporation, and condensation contribute various errors in back trajectory calculations $[12,18,19]$. A review of the associated errors and probabilities within them related to back trajectories has been provided by Polissar and coworkers [13].

1.3. Basic Calculation of Airmass Trajectories. A trajectory can be defined by a differential equation

$$
\frac{d r}{d t}=v[r(t)]
$$

where $r(t)$ is position vector at time $t$ and $v$ is the velocity field.

Assuming a two-dimensional flow, Seibert suggested the following numerical solution [20]:

$$
\begin{gathered}
x_{1}=x_{0}+\Delta t u\left(x_{0}, y_{0}, t\right), \\
y_{1}=y_{0}+\Delta t v\left(x_{0}, y_{0}, t\right), \\
x_{n}=x_{0}+0.5 \Delta t\left[u\left(x_{0}, y_{0}, t\right)+u\left(x_{n-1}, y_{n-1}, t+\Delta t\right)\right], \\
y_{n}=y_{0}+0.5 \Delta t\left[v\left(x_{0}, y_{0}, t\right)+v\left(x_{n-1}, y_{n-1}, t+\Delta t\right)\right],
\end{gathered}
$$

where $\left(x_{0}, y_{0}\right)=$ starting position at time $t, x_{n}, y_{n}=n$th iteration of the position for the time $t+\Delta t, u=$ function of space, and $v=$ function of time.

Details of higher trajectory solutions can be found in Isaacson and Keller and Brumer [21, 22].

1.4. Trajectory Models. Table 1 gives the list of various models used for the calculation of the trajectories. According to the available reports worldwide, HYSPLIT (hybrid single particle Lagrangian integrated trajectory) model has been
TABLE 1: List of various airmass trajectory models used worldwide.

\begin{tabular}{lc}
\hline Trajectory models & References \\
\hline NMC (US National Meteorological Centre) & {$[23]$} \\
Flexible Trajectories (FLEXTRA) model & {$[24]$} \\
TRADOS model (Finnish Meteorological Institute) & {$[25]$} \\
CMDC (Climate Monitoring and Diagnostics & {$[13]$} \\
Laboratory) & \\
UK Universities' Global Atmospheric Modelling & {$[26]$} \\
Programme (UGAMP) model & \\
Hybrid Single-Particle Lagrangian Integrated & {$[27]$} \\
Trajectory (HYSPLIT) model & \\
NIES (Russian National Institute for Environmental & {$[28]$} \\
Studies) & \\
Centre for Air Pollution Impact and Trends Analysis & {$[29]$} \\
CAPITA Monte Carlo (CMC) model & \\
APTRA model & {$[30]$} \\
$\begin{array}{l}\text { European Centre for Medium-Range Weather } \\
\text { Forecasts (ECMWF) three-dimensional isentropic } \\
\text { model }\end{array}$ & {$[31]$} \\
LAGRANTO model & \\
COSMO TRAJ & {$[32]$} \\
CAABA/MJT model & {$[33]$} \\
COBRA & {$[34]$} \\
Stochastic Time-Inverted Lagrangian Transport & {$[35]$} \\
(STILT) model & {$[36]$} \\
\end{tabular}

applied in most of the studies [27, 37-41]. The model has been developed by NASA. Besides airmass trajectories, the model also computes dispersion and disposition simulations. Very recently HYSPLIT model has been upgraded. However, FLEXTRA model has also been used by various workers worldwide [3, 14, 15]. Recently, web based system called READY (real-time environmental applications and display) system is developed by the Air Resources Laboratory (ARL). READY is also being used to run trajectory and dispersion model accessing and displaying meteorological data. Simultaneous application of dispersion models, graphical display programs, and textual forecast programs makes this system very useful for atmospheric scientists.

1.5. Applications of Trajectories. In the beginning, trajectories were used to find out the source region and transport processes of air pollution, but, with the advancement of knowledge, trajectories are found to be useful to address various aspects related to atmosphere and environment, as shown in Figure 1. Trajectories are applied in various fields such as climatology [42], meteorology [43], transport of pollutants $[9,14,44,45]$, residence time analysis [46], air quality $[47,48]$, source apportionment $[49,50]$, aerosol measurements [51-53], precipitation chemistry [54, 55], and policies [56].

Tarasick and coworkers have used backward and forward trajectories to produce ozone maps using North American ozonesonde data linking it to the grid points of the trajectory pathways [57]. This approach was found to be 


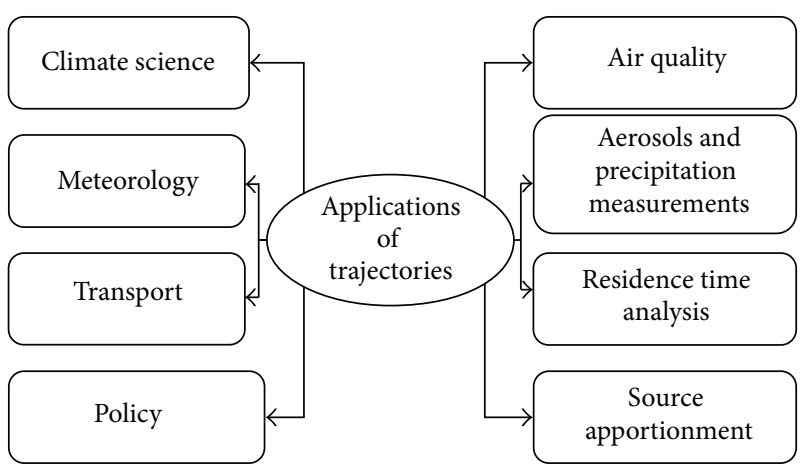

FIGURE 1: Applications of airmass trajectories in various fields.

very successful in providing trajectory mapped ozone values having reasonable agreement with the actual soundings. Trajectories have been used to isolate periods of stratospheretroposphere (S-T) exchange at several rural sites in the United States by Lefohn and coworkers [58]. Trajectory models have been used to study circulation of pollutants [59] including dust storm trajectory simulations. Ashrafi and coworkers attempted such simulations over Iran using dust module of HYSPLIT model which is primarily based on the $\mathrm{PM}_{10}$ dust emissions for desert areas [60]. According to their findings dust motion simulations obtained from the model were similar to the MODIS images.

1.6. Trajectories and Air Pollution Transport in South Asia. A number of studies have been reported on air pollution transport using airmass trajectories in South Asia. Table 2 gives the list of most of the studies on airmass trajectory calculations to demonstrate transboundary and long range transport of air pollution in South Asian countries. Because of large volume of work reported on various aspects of trajectories, it is not possible to describe all these studies in this review. However, we have tried to highlight major pathways of air pollution transport and their wet deposition in South Asian region by describing few important studies in various parts of South Asian region.

1.6.1. Bangladesh. Transboundary air pollution in South Asian countries, namely, Bangladesh, India, Pakistan, and Sri Lanka, has been reported by Brumer to find out the source areas that are primarily responsible for the transport of pollutants [22]. During this study, simultaneous sampling of particulate matter using similar methodology was carried out in Bangladesh, India, Pakistan, and Sri Lanka. According to their report, $\mathrm{BC}$ rich smoke is contributed by agricultural waste burning sources located mainly in Northern India (Figure 2). Fine soil is contributed by the dust storms due to which particulate matter levels are enhanced in the air. Based upon the trajectories, they observed that long range transport of the desert dust from Oman through the Gulf and Iran is transported to Pakistan and other South Asian countries.

Saadat and coworkers reported that transboundary transport of pollutants has significant impact on air quality of Bangladesh due to the industrial activities of neighboring countries India and China [39]. The levels of $\mathrm{SO}_{x}$ and $\mathrm{NO}_{x}$ were recorded to be higher whenever airmass movement was noticed through India (North and North West). However, the levels of these gases were recorded significantly to be lower when the airmasses passed through India but spent enough time over Bay of Bengal. Using HySPLIT model and 10-day backward trajectories, Iqbal and Oanh observed that majority of airmasses arriving to Bangladesh were originated from the west [62]. However, according to their inventory report, 70\% of $\mathrm{SO}_{2}$ emissions in Dhaka division were attributed to local brick kilns.

1.6.2. Indian Ocean. There are a very limited number of wet deposition studies using trajectories which have been reported over Indian Ocean. However, studies on aerosol transport over Indian Ocean have been reported by several workers (Table 2). Granat and coworkers (2002) have reported rainwater chemistry in Indian Ocean region during the Indian Ocean Experiment (INDOEX) campaign held in January-March 1999 [54]. Samples collected onboard the research vessels Ronald $H$. Brown and Sagar Kanya were analyzed for major ions and some trace metals. They calculated air trajectories arriving at the location of the ship (at 950 ha) with the McGrath trajectory model using wind and mass fields from ECMWF. Five patterns of trajectories around the Indian Ocean have been reported in this paper. Airmass trajectories analysis (Figure 3) revealed that very high concentrations of non-seasalt $\mathrm{SO}_{4}{ }^{2-}, \mathrm{NO}_{3}{ }^{-}, \mathrm{NH}_{4}{ }^{+}$, nss$\mathrm{K}^{+}$, and non-seasalt $\mathrm{Ca}^{2+}$ in rainwater over the Indian Ocean were due to the influence of pollution and soil sources in Asia.

Long range transport of dust and other pollutants over Indian Ocean has been reported by couple of workers. Most of these studies have been part of INDOEX and focused upon the aerosol optical depth (AOD) or the monsoon circulations. Krishnamurti and coworkers have reported the possibility of long range transport of dust from Arabian Desert to the central Indian Ocean region with a transit time of 2-3 days [66]. Li and Ramanathan presumed that long range transport of dust from the Horns of Africa over the Arabian Sea and mid tropospheric transport of dust from the Arabian Peninsula can affect the summer monsoon and can lead to higher aerosol loadings in south of the equator [65]. According to them, long range transports of emissions from Indonesia forest fires in 1997 were responsible for increase in AODs over most of the equatorial Indian Ocean. Verma and coworkers have used a hybrid approach to find out the pathways of pollutant transport over Indian Ocean during Intensive Field Phase of INDOEX during JanuaryMarch 1999 [67]. They used an Eulerian forward transport calculation in a general circulation model (GCM) with region-tagged emissions along with an analysis of Lagrangian back trajectories and emission inventory for overlapping time periods. They found that, during the early part of the cruise when ship was moving over Indian Ocean, airmasses from the Indo-Gangetic Plain, Central India, or South India transported sulphate aerosols and organic matter over to Indian Ocean. But during late February-early March when ship was moving in the Arabian Sea, dust species dominated 


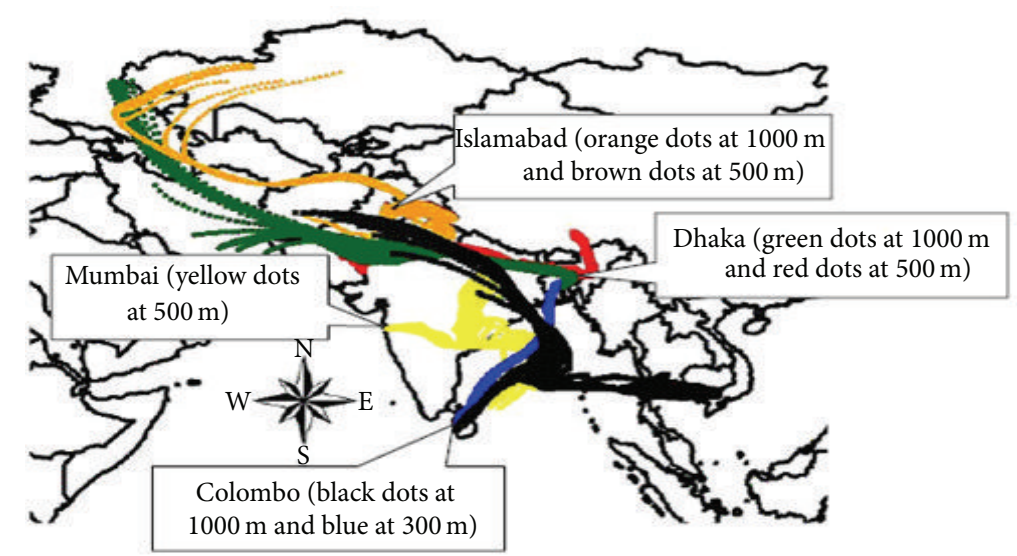

FIGURE 2: Air parcel back trajectories showing the likely source areas for smoke in India, Bangladesh, Pakistan, and Sri Lanka [38].

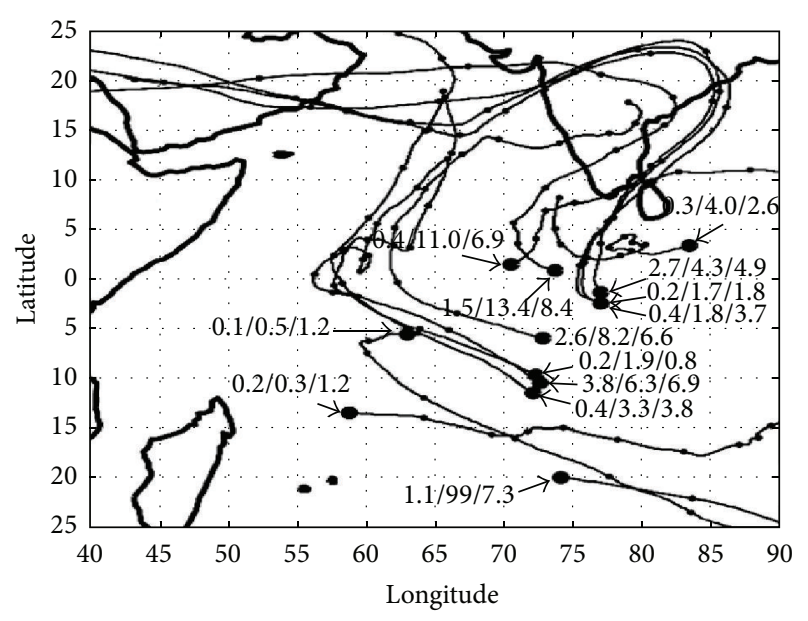

Figure 3: Measured concentration $\left(\mu\right.$ mold m $\left.{ }^{-3}\right)$ of nss- $\mathrm{Ca}^{2+}, \mathrm{NH}_{4}{ }^{+}$, and nss- $\mathrm{SO}_{4}{ }^{2-}$ and associated 10-day backwards trajectories for each rain sample; dots show the point of sample collection along the cruise tracks of ships during INDOEX 1999 [54].

which were transported by the airmasses from Africa, West Asia, or Northwest India.

Generally, higher pollution is reported in the north of equator in Indian Ocean [54] as most of the emission sources are located in northern hemisphere. Relatively pristine atmosphere is observed in Southern Indian Ocean due to negligible human perturbations. However, the search operation for missing Malaysian airlines flight MH 370 is expected to emit large amount of aerosols and gaseous pollutants in Southern Indian Ocean due to fuel burning by a number of searching aircrafts and ships. More than a month long operation had used around 20 aircrafts and 20 ships. According to BBC (http://www.bbc.com/news/world-asia-26514556), this has been the largest search operation which covered 7.68 million sq $\mathrm{km}$ area which is equivalent to $11 \%$ of the Indian Ocean and $1.5 \%$ of the surface of the Earth. In this relation, the calculations of airmass trajectories can be of great help to find out the pathways of transport of air pollutants in Southern Indian Ocean. Scavenging of various aerosols and gaseous pollutants can modify the clouds in south of intertropical convergence zone (ITCZ) which can further affect monsoon process.

1.6.3. Bay of Bengal and Arabian Sea. Deposition of acidic components has been reported over Bay of Bengal and Arabian Sea by Reddy and coworkers [52]. This study was carried out during Integrated Campaign on Aerosol and trace gas Radiative Forcing (ICARB). They observed that the air over Bay of Bengal and Arabian Sea was influenced by the airmasses coming from four sectors: (i) passing through Indian land, (ii) from Indian Ocean region, (iii) form Northern Arabian Sea and Middle East, and (iv) from African continent. Figure 4 shows the origin of airmasses reaching various cruise points over Bay of Bengal and Arabian Sea. The highest nss- $\mathrm{SO}_{4}{ }^{2-}$ was observed during airmasses coming from the Indian land while the lowest concentrations were observed when the airmasses were coming from oceanic region. However, total fluxes of pollutants contributed by the airmasses of different direction are not estimated in any of the studies reported in this region.

1.6.4. Maldives. Most of the studies reported from Maldives are part of Atmospheric Brown Cloud (ABC) project as $\mathrm{MCOH}$ Climate Observatory is located at Hanimaadhoo Island. Transport of pollutants up to $\mathrm{MCOH}$ has been reported by Das and coworkers [68]. They have used airmass trajectories to interpret the water soluble inorganic components in rain deposited at $\mathrm{MCOH}$ to find out seasonality and possible source regions. The concentrations of non-seasalt $\mathrm{SO}_{4}{ }^{2-}, \mathrm{NH}_{4}{ }^{+}$, and $\mathrm{NO}_{3}{ }^{-}$were observed to be higher by a factor of 4 when airmasses arrived from India as compared to the marine airmasses. Such effect resulted in very low $\mathrm{pH}$ of rainwater (4.7), which was significantly lower than the $\mathrm{pH}$ values (6.0) contributed by the marine airmasses. Figure 5 shows the trajectories arriving at $\mathrm{MCOH}$ (Hanimaadhoo). 
TABLE 2: Summary of trajectory studies reported in South Asia.

\begin{tabular}{|c|c|c|c|c|c|}
\hline Location & Country/region & Latitude and longitude & Trajectory model used & Components measured & References \\
\hline Arabian Sea & Arabian Sea & $\begin{array}{l}9.0^{\circ} \mathrm{N} \text { to } 22^{\circ} \mathrm{N} \\
58^{\circ} \mathrm{E} \text { to } 77.3^{\circ} \mathrm{E}\end{array}$ & $\begin{array}{l}\text { CGER METEX } \\
\text { programme }\end{array}$ & $\begin{array}{c}\text { Major ions (PM10 } \\
\text { aerosols) }\end{array}$ & {$[52]$} \\
\hline INDOEX & $\begin{array}{l}\text { Arabian Sea and } \\
\text { Indian Ocean }\end{array}$ & Multiple points & Wind data (NCEP) & $\mathrm{AOD}$ & {$[61]$} \\
\hline Dhaka (AECD) & Bangladesh & $23.73^{\circ} \mathrm{N}, 90.40^{\circ} \mathrm{E}$ & HYSPLIT & $\mathrm{BC}$, aerosol & {$[38]$} \\
\hline Sathkhira & Bangladesh & $22.18^{\prime} \mathrm{N} 89.02^{\prime} \mathrm{E}$ & HYSPLIT & SOx, NOx & [39] \\
\hline Dhaka & Bangladesh & $23.73^{\circ} \mathrm{N}, 90.40^{\circ} \mathrm{E}$ & HYSPLIT & $\begin{array}{l}\text { SOx, NOx, CO, } \\
\text { NMVOC, and PM }\end{array}$ & {$[62]$} \\
\hline Bay of Bengal & Bay of Bengal & $\begin{array}{l}20.5^{\circ} \mathrm{N} \text { to } 5.6^{\circ} \mathrm{N} \\
80.4^{\circ} \mathrm{E} \text { to } 93.4^{\circ} \mathrm{E}\end{array}$ & $\begin{array}{l}\text { CGER METEX } \\
\text { programme }\end{array}$ & $\begin{array}{l}\text { Major ions (PM10 } \\
\text { aerosols) }\end{array}$ & {$[52]$} \\
\hline Navi Mumbai & India & $19.07^{\circ} \mathrm{N}, 72.97^{\circ} \mathrm{E}$ & HYSPLIT & $\mathrm{BC}$, aerosol & {$[38]$} \\
\hline Hudegade, Western Ghats & India & $14.36^{\circ} \mathrm{N}, 74.54^{\circ} \mathrm{E}$ & HYSPLIT & Major ions (rain) & {$[55]$} \\
\hline Sinhagad & India & $18^{\circ} 21^{\prime} \mathrm{N}, 73^{\circ} 45^{\prime} \mathrm{E}$ & HYSPLIT & Major ions (cloud water) & {$[41]$} \\
\hline Sinhagad & India & $18^{\circ} 21^{\prime} \mathrm{N}, 73^{\circ} 45^{\prime} \mathrm{E}$ & HYSPLIT & Major ions (rain water) & {$[40]$} \\
\hline Sinhagad & India & $18^{\circ} 21^{\prime} \mathrm{N}-73^{\circ} 45^{\prime} \mathrm{E}$ & $\begin{array}{l}\text { McGrath (1989) model } \\
\text { with ECMWF }\end{array}$ & $\begin{array}{c}\mathrm{pH} \text { and major ions (rain } \\
\text { water) }\end{array}$ & {$[63]$} \\
\hline Pune & India & $18^{\circ} 32^{\prime} \mathrm{N}-73^{\circ} 51^{\prime} \mathrm{E}$ & $\begin{array}{l}\text { McGrath (1989) model } \\
\text { with ECMWF }\end{array}$ & $\begin{array}{c}\mathrm{pH} \text { and major ions (rain } \\
\text { water) }\end{array}$ & {$[63]$} \\
\hline Goa & India & $15^{\circ} 45^{\prime} \mathrm{N}-73^{\circ} 85^{\prime} \mathrm{E}$ & $\begin{array}{l}\text { McGrath (1989) model } \\
\text { with ECMWF }\end{array}$ & $\begin{array}{c}\mathrm{pH} \text { and major ions (rain } \\
\text { water) }\end{array}$ & {$[63]$} \\
\hline Bhubaneshwar & India & $20^{\circ} 15^{\prime} \mathrm{N}-85^{\circ} 52^{\prime} \mathrm{E}$ & $\begin{array}{l}\text { McGrath (1989) model } \\
\text { with ECMWF }\end{array}$ & $\begin{array}{c}\mathrm{pH} \text { and major ions (rain } \\
\text { water) }\end{array}$ & {$[63]$} \\
\hline Manali & India & $32.31^{\circ} \mathrm{N}, 77.20^{\circ} \mathrm{E}$ & HYSPLIT & $\begin{array}{c}\mathrm{pH} \text { and major ions } \\
\text { (snowfall) }\end{array}$ & {$[64]$} \\
\hline Anantpur & India & $14.62^{\circ} \mathrm{N}, 77.65^{\circ} \mathrm{E}$ & HYSPLIT & $\mathrm{O} 3$ & {$[37]$} \\
\hline INDOEX & Indian Ocean & $\begin{array}{c}30^{\circ} \mathrm{N} \text { to } \sim 35^{\circ} \mathrm{S}, 40^{\circ} \mathrm{E} \text { to } \\
\left.\sim 100^{\circ} \mathrm{E}\right)\end{array}$ & $\begin{array}{l}\text { No (wind data from } \\
\text { NCEP/NCAR) }\end{array}$ & AOD & {$[65]$} \\
\hline INDOEX & Indian Ocean & Multiple points & No & $\mathrm{AOD}$ & {$[66]$} \\
\hline INDOEX & Indian Ocean & Multiple points & $\begin{array}{l}\text { McGrath model with } \\
\text { ECMWF }\end{array}$ & $\begin{array}{c}\mathrm{pH} \text { and major ions (rain } \\
\text { water) }\end{array}$ & [54] \\
\hline INDOEX & Indian Ocean & $\begin{array}{c}20^{\circ} \mathrm{S} \text { to } 17.2^{\circ} \mathrm{N} \text { and } 57.5^{\circ} \mathrm{E} \\
\text { to } 77^{\circ} \mathrm{E}\end{array}$ & $\begin{array}{l}\text { HYSPLIT (hybrid } \\
\text { approach) }\end{array}$ & $\mathrm{BC}$, sulphate (aerosol) & {$[67]$} \\
\hline $\mathrm{MCOH}$ & Maldives & $6^{\circ} 46^{\prime} \mathrm{N}$ and $73^{\circ} 11^{\prime} \mathrm{E}$ & HYSPLIT & $\begin{array}{c}\mathrm{pH} \text { and major ions (rain } \\
\text { water) }\end{array}$ & {$[68]$} \\
\hline Nilore & Pakistan & $33.37^{\circ} \mathrm{N}, 73.06^{\circ} \mathrm{E}$ & HYSPLIT & $\mathrm{BC}$, aerosol & {$[38]$} \\
\hline Multiple sites & Pakistan & Multiple points & HYSPLIT & AOD & {$[69]$} \\
\hline Colombo & Sri Lanka & $6.933^{\circ} \mathrm{N}, 79.833^{\circ} \mathrm{E}$ & HYSPLIT & BC, aerosol & {$[38]$} \\
\hline Delhi & India & $28.38^{\circ} \mathrm{N}, 77.12^{\circ} \mathrm{E}$ & HYSPIT & Rain chemistry & {$[70]$} \\
\hline New Delhi & India & $28.6^{\circ} \mathrm{N}, 77.2^{\circ} \mathrm{E}$ & HYSPLIT & AOD & {$[71]$} \\
\hline
\end{tabular}

1.6.5. Nepal. Trajectory analysis for wet deposition in Nepal has not been reported. However, according to MISU data collected for rain chemistry at $\mathrm{ABC}$ observational site Godavari indicated that airmasses from sectors are received at the observatory. These included (i) from Arabian Sea passing over India, (ii) from Bay of Bengal passing through Bangladesh, (iii) from Middle East, and (iv) from Europe [67]. Sometimes, airmasses were coming from Southeast Asia through Myanmar, Bangladesh, and India. However, our recent observations on snow chemistry at Manali in Himachal Pradesh revealed that airmasses coming from Nepal were found to be responsible for air pollution transport to India. Such trajectories have been discussed in the last section of this paper.

1.6.6. India. India has the highest landmass, population, and natural resources, as well as the largest industrial setup among all the South Asian countries. Hence, it can be termed as the biggest pollution exporter to the nearby countries and oceanic regions. At the same time India imports huge amount of pollution through long range transport from Europe, Middle East, Africa, Indian Ocean, and nearby countries. However, the amount of such import and export of pollution 


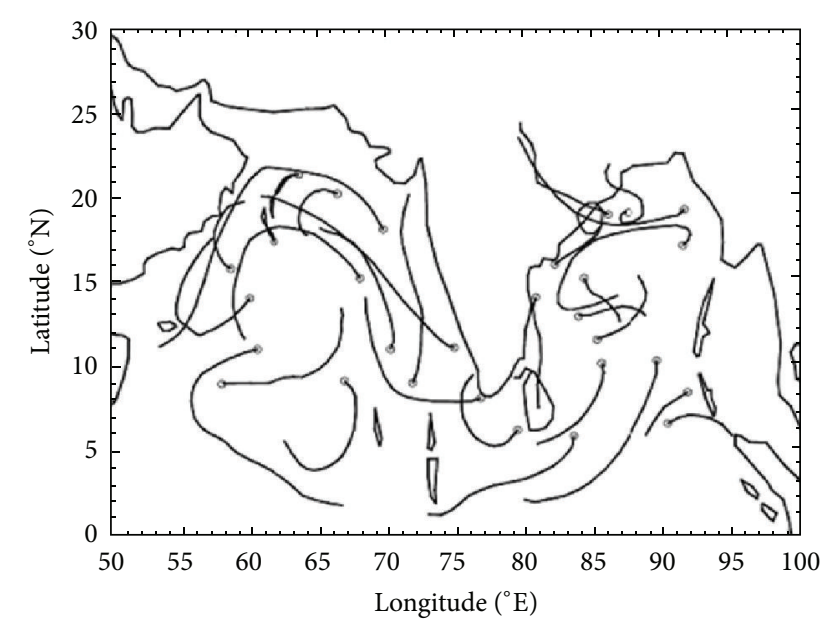

FIgUre 4: Airmass trajectories over Bay of Bengal and Arabian Sea during ICARB [52].

from different sectors has not been estimated due to absence of regional emission regulatory body. 1979 Geneva Convention on Long-range Transboundary Air Pollution (CLRTAP) is one such ideal example which aims to limit and, as far as possible, gradually reduce and prevent air pollution including long-range transboundary air pollution by each participating country [72]. CLRTAP has 51 parties so far.

Most of the studies given in Table 2 have reported the origin of airmasses and the type of pollutants contributed by these airmasses. The reported information using trajectories is highly useful in order to understand the sources and pathways of pollution transport to various sites in India. Satyanarayana and co-workers noticed that the long range transport of pollution from various sectors significantly affected the $\mathrm{pH}$ and chemistry of rain water at Hudegadde, a rural site located in an ecological sensitive area of Western Ghats [55]. They observed that Hudegade received the airmasses from five different sectors, namely, central part of Indian Ocean, Northwest Indian Ocean, Southwest Indian Ocean, and Gulf and airmasses passing through Northwest Indian Ocean and south continental part of India. Airmass trajectory analysis suggested a significant influence of local and intercontinental anthropogenic and natural sources. Sources located in the African and Gulf regions had influenced the acidity at the site. They found that urban activities located in southwest of Indian continent (north of sampling site) and the sources in Gulf region were responsible for acid rain in Western Ghats (Table 3).

Chemical composition of precipitation during different trajectory classes has been reported by Norman and coworkers (2001) at Bhubaneshwer, Goa, Sinhagad, and Pune [63]. They compared the rain chemistry results with trajectories and precipitation fields. As shown in Table 4, a systematic change in chemical composition and $\mathrm{pH}$ of rain water was noticed in accordance with the origin of airmasses and the amount of rainfall along the trajectory. Bhubaneswar which is located in Eastern India received airmasses from Arabian Sea, Bay of Bengal, and continental sources. Different trajectories arriving to Bhubaneshwar have been shown in Figure 6.
TABLE 3: Concentrations $\left(\mu \mathrm{eq} \mathrm{L}^{-1}\right)$ of major ions in different airmasses at the site (source: [55]).

\begin{tabular}{lccccc}
\hline & C.I.O. & N.W.I.O & S.W.I.O. & Gulf & N.W.I.O. + S.W.I.C. \\
\hline $\mathrm{Cl}^{-}$ & 12 & 40 & 64 & 0.3 & 0.3 \\
$\mathrm{NO}_{3}{ }^{-}$ & 4 & 29 & 9 & 11 & 13 \\
$\mathrm{nss} \mathrm{SO}_{4}{ }^{2-}$ & 11 & 35 & 35 & 12 & 16 \\
$\mathrm{Na}^{+}$ & 16 & 45 & 59 & 7 & 3 \\
$\mathrm{NH}_{4}{ }^{+}$ & 5 & 28 & 2 & 2 & 4 \\
$\mathrm{~K}^{+}$ & 5 & 3 & 9 & 16 & 2 \\
$\mathrm{nss} \mathrm{Ca}^{2+}$ & 38 & 71 & 68 & 21 & 3 \\
\hline
\end{tabular}

C.I.O.: Central Indian Ocean; N.W.I.O.: Northwest Indian Ocean; S.W.I.O.: Southwest Indian Ocean; N.W.I.O. + S.W.I.C.: Northwest Indian Ocean + Southwest Indian Continent.

From West India, most of wet deposition studies have been reported for Pune region. Using airmass trajectories, Begum and coworkers (2011) observed that the long range of transport of air pollutants and dust was responsible for elevated levels of selected ions in cloud water at Sinhagad which is a high altitude side near Pune [38]. In another study at Sinhagad, Reddy and coworkers (2010) observed that monsoon and postmonsoon airmasses had their origin from different directions affecting rain chemistry accordingly [37]. As shown in Figure 7, during monsoon season, air moved from African region. But during postmonsoon season, air parcel is seen originating from Middle East and Europe travelling through North India and finally reaching Sinhagad. Authors have reported that, due to this reason, the concentrations of $\mathrm{NO}_{3}{ }^{-}, \mathrm{NH}_{4}{ }^{+}, \mathrm{nss}_{-} \mathrm{SO}_{4}{ }^{2-}$, and nss- $\mathrm{K}^{+}$were observed to be higher in postmonsoon samples as compared to monsoon samples.

\subsubsection{Long Range Transport up to Western Himalayan Ranges.} In order to observe the airmass movement in North India up to the Western Himalaya, we carried out snow chemistry study coupled with trajectory analysis. In our study, the samples of snowfall were collected at a high altitude site Kothi $\left(32.31^{\circ} \mathrm{N}, 77.20^{\circ} \mathrm{E}\right)$ located in Kullu district of Himachal Pradesh state of India, which were processed for chemical analysis. Five-day back trajectories at $5000 \mathrm{~m}$ altitude were calculated for these samples using HYSPLIT model from NOAA [27]. Airmass trajectories revealed that Kothi was receiving snowfall through the airmasses originating from six major sectors which are termed as (1) North Atlantic Ocean origin (NAO), (2) African origin (Af), (3) Middle East origin (ME), (4) European origin (Eu), (5) West India origin (WI), and (6) Nepal origin (Np). Figures 8(a)-8(f) show typical examples of these trajectories.

North Atlantic Ocean Origin (NAO). Airmasses originating from North Atlantic Ocean and passing over Europe to Afghanistan to Jammu and Kashmir and reaching the sampling site, that is, Kothi, have been referred to as NAO (Figure $8(\mathrm{a})$ ). This cluster represented the highest number of events $(40 \%)$.

African Origin (Af). Airmasses originating from African continent and passing over Middle East/Gulf to Pakistan 


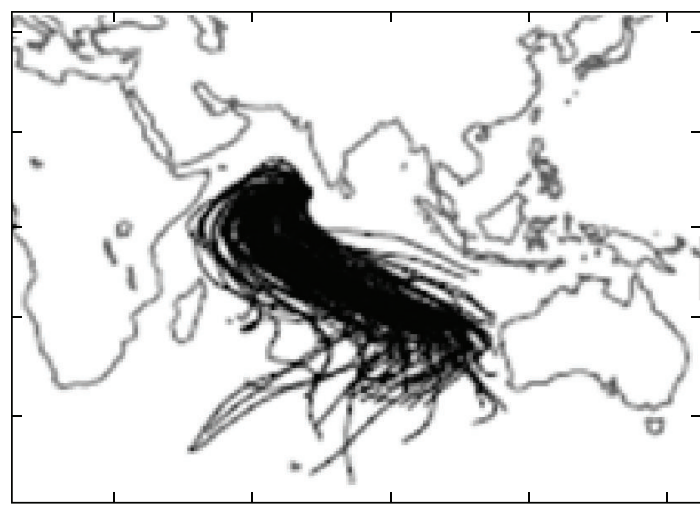

(a) Marine

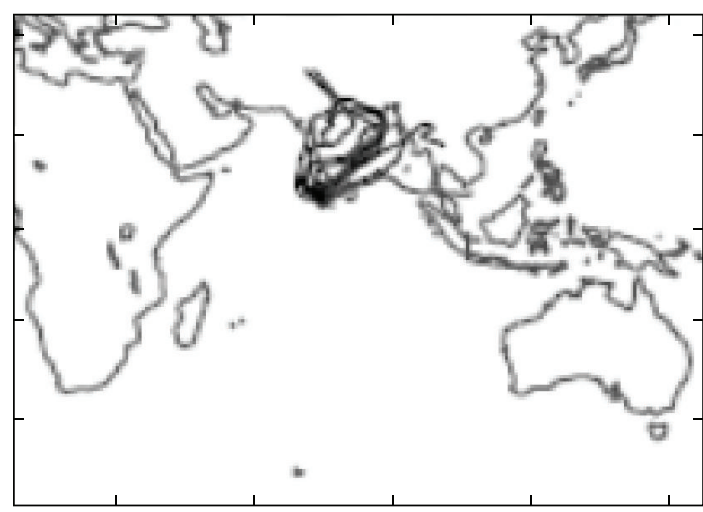

(c) Indian

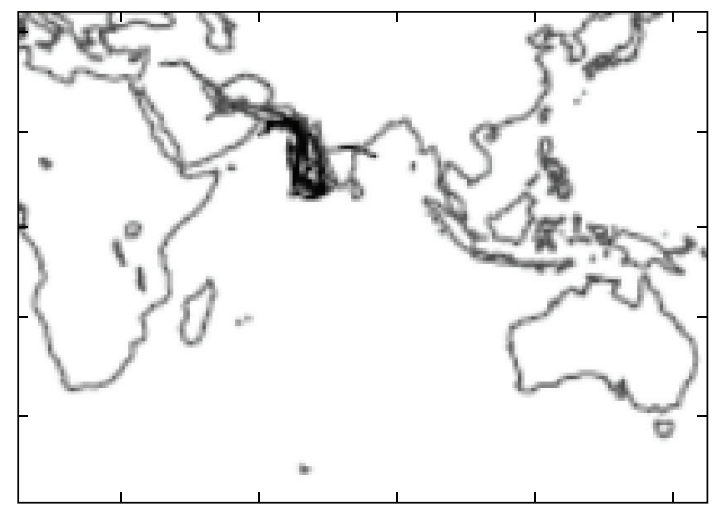

(b) Arabian Sea

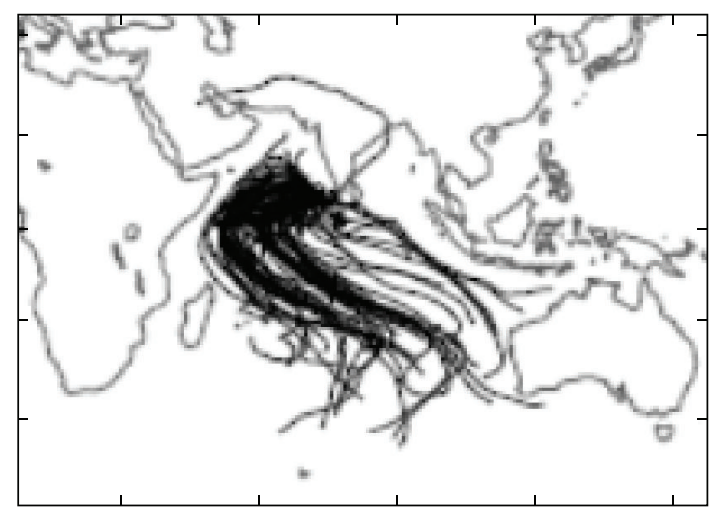

(d) Mixed

FIgUre 5: Classification of trajectories arriving at MCOH, (a) Marine, (b) Arabian Sea, (c) Indian, and (d) mixed [68].

TABLE 4: Median concentrations $\left(\mathrm{mmol} \mathrm{L}^{-1}\right)$ in rain samples at Bhubaneswar for different trajectory groups and frequency of rain along the trajectory $([63])$.

\begin{tabular}{|c|c|c|c|c|c|c|c|c|c|c|c|c|}
\hline Sample group & $\mathrm{pH}$ & $\mathrm{Na}^{+}$ & $\mathrm{NH}_{4}^{+}$ & $\mathrm{K}^{+}$ & $\mathrm{Mg}^{2+}$ & $\mathrm{Ca}^{2+}$ & $\mathrm{Cl}^{-}$ & $\mathrm{NO}_{3}{ }^{-}$ & $\mathrm{SO}_{4}{ }^{2-}$ & nss- $\mathrm{SO}_{4}{ }^{2-}$ & $\mathrm{Ca}^{2+} / \mathrm{Na}^{+}$ & Number of samples \\
\hline \multicolumn{13}{|c|}{ High rain frequency } \\
\hline $\mathrm{C}$ & 5.48 & 6.3 & 22.2 & 1.2 & 1.3 & 3.1 & 6.5 & 9.4 & 6.8 & 6.5 & 0.66 & 18 \\
\hline $\mathrm{CL}$ & 4.84 & 28.2 & 73.5 & 9.4 & 6.9 & 28.1 & 34.7 & 53.8 & 37 & 35.3 & 0.79 & 2 \\
\hline B & 5.54 & 6.1 & 9.1 & 0.5 & 0.7 & 1.5 & 7.5 & 2.5 & 3.1 & 2.8 & 0.25 & 14 \\
\hline M & 5.82 & 11.9 & 20.7 & 1.1 & 11.6 & 7.2 & 12.6 & 10.9 & 8.9 & 6.7 & 0.53 & 23 \\
\hline \multicolumn{13}{|c|}{ Low rain frequency } \\
\hline $\mathrm{C}$ & 5.61 & 16.9 & 44.7 & 3.7 & 3.8 & 10.5 & 23 & 29 & 21.2 & 19.6 & 0.58 & 21 \\
\hline CL & 5.03 & 18.2 & 52.6 & 4.5 & 5 & 28.4 & 20 & 44 & 40.2 & 39.1 & 2.33 & 2 \\
\hline B & 5.28 & 31.8 & 81.3 & 7.9 & 6.3 & 17.7 & 34.5 & 49 & 36.7 & 35.8 & 0.8 & 6 \\
\hline $\mathrm{M}$ & 5.77 & 12.4 & 11.3 & 0.6 & 2.4 & 5 & 14.5 & 9.4 & 9.2 & 8.4 & 0.56 & 8 \\
\hline
\end{tabular}

Note: (a) continental (C), (b) continental local (CL), (c) monsoon (M), and (d) Bay of Bengal (B).

before reaching the sampling site have been termed as Af. This cluster represented $23 \%$ of snowfall events. Figure 8 (b) is a typical example of such airmasses.

Middle East Origin (ME). Airmasses originating from Middle East and reaching the sampling site via Pakistan and Haryana have been termed as ME. This group represented $10 \%$ of the total snowfall events. Figure 8(c) is a typical example of ME airmasses.
European Origin $(\mathrm{Eu})$. Airmasses originating from continental Europe and reaching the sampling site via Afghanistan and Jammu and Kashmir have been referred to as Eu. This class represented the least number (6\%) of snowfall events. Figure 8(d) is a typical example of such airmasses.

Western India Origin (InW). Airmasses originating in Western India in the state of Rajasthan and transported over 


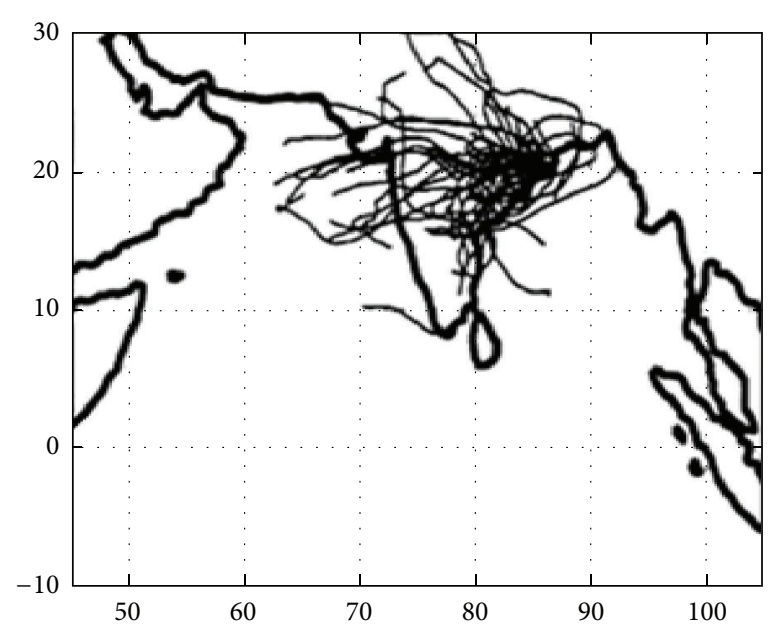

(a) Continental

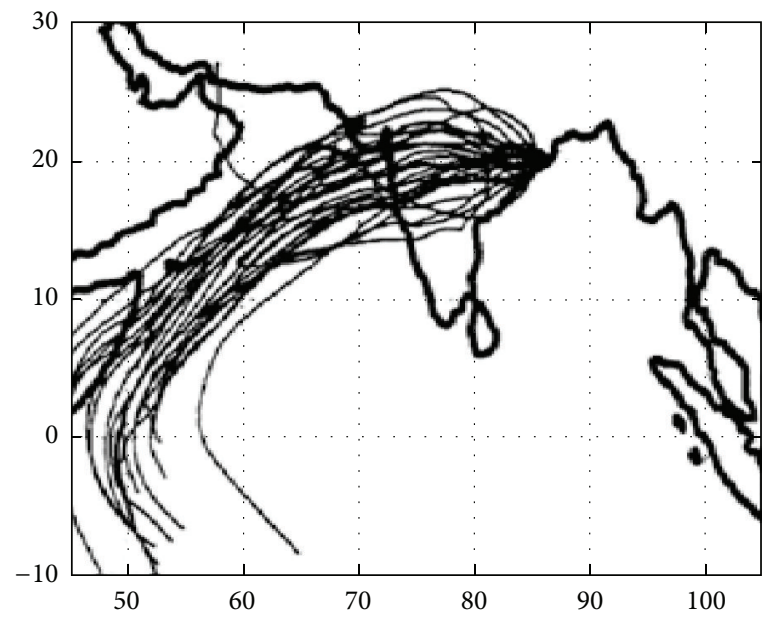

(c) Monsoon

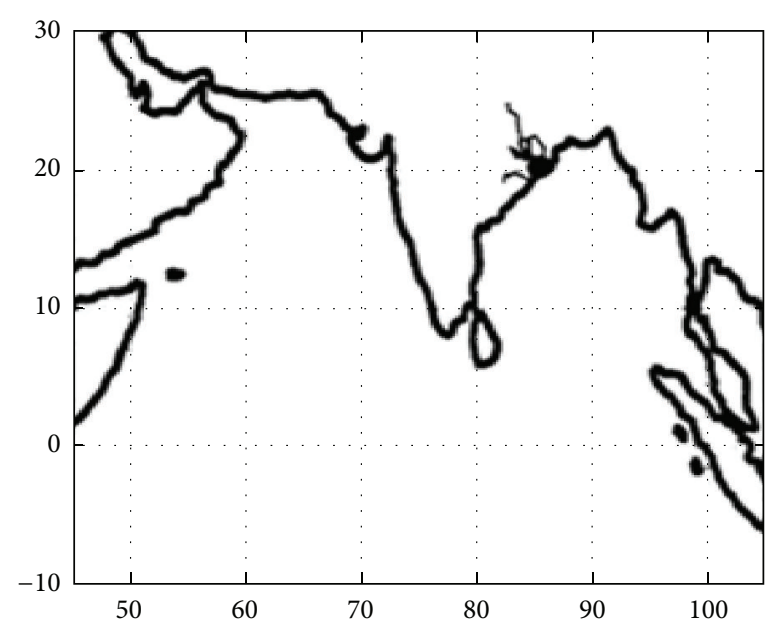

(b) Continental Local

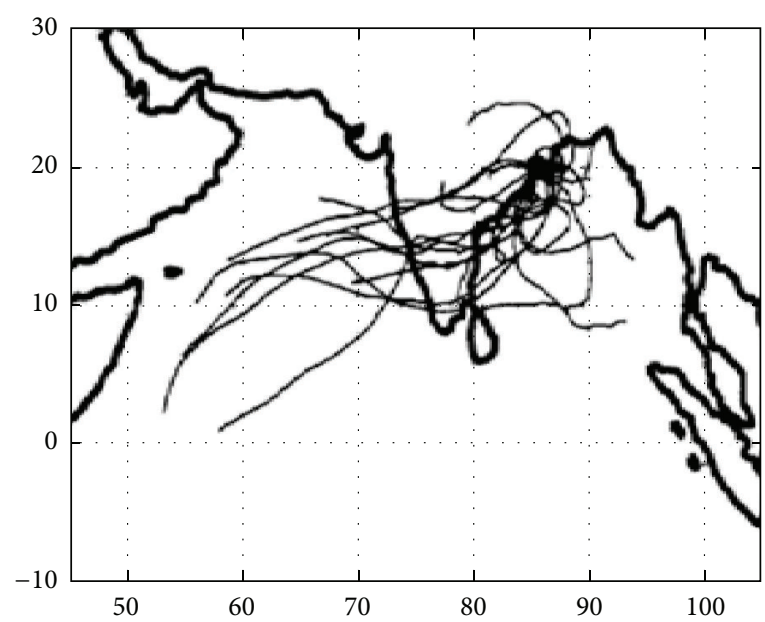

(d) Bay of Bengal

Figure 6: Trajectories to Bhubaneswar, sorted into different trajectory groups during January 1997-October 1998. (a) Continental (C), (b) continental local (CL), (c) monsoon (M), and (d) Bay of Bengal (B) [63].

Punjab and Haryana and, finally, reaching the sampling site have been termed as InW. This group represented $13 \%$ of the total snowfall events. Figure $8(\mathrm{e})$ is a typical example of this type of airmasses.

Nepal Origin (Np). Airmasses originating from Nepal side reaching the sampling site via Uttarakhand have been categorized as Np. This cluster represented the second lowest number of events (8\%). Figure $8(\mathrm{f})$ is a typical example of this type of airmasses.

In general, $\mathrm{pH}$ of the samples varied from 4.75 to 6.98 with an average value of 5.69 indicating slight alkaline nature of snow samples. Slight alkaline precipitation has been reported at higher altitude in Indian region [40, 41, 73-75]. Figure 9 shows the percent frequency distribution of $\mathrm{pH}$ of snowfall samples. Maximum number of samples had $\mathrm{pH}$ between 6.21 and $6.60(29 \%)$ followed by a range of 5.81-6.20 (25\%), 6.61-7.00 (17\%), 5.41-5.80 (17\%), 4.61-5.00 (10\%), and 5.01$5.40(4 \%)$. The high $\mathrm{pH}(\mathrm{pH}>5.6)$ has been reported in global precipitation samples due to the influence of soil derived particulate matter $[40,68,76-80]$. Out of total, $83 \%$ of samples showed $\mathrm{pH}$ of snow above 5.6 , while $17 \%$ of samples only were found to be acidic at Kothi. Acidic snow samples were found at this site in airmasses originated from Middle East Countries and Europe mainly. Acidic pH has been reported in precipitation samples in airmasses originated from Europe [80] and Gulf countries [55]. 43\% of rain samples were observed to be acidic in nature at state botanical garden in Bhubaneswar, India [81]. 18\% occurrence of acid rain has been reported at Delhi, India [76]. $\mathrm{pH}$ value ranged between 3.98 and 8.01 with $20 \%$ acidic precipitation samples having been reported at Montseny in Northeast Spain, Europe [80]. Out of total precipitation samples, $21 \%$ of samples were found to be acidic in nature at Sinhagad, Pune, India [82]. 79.3\% of the total precipitation has a $\mathrm{pH}$ value less than 5.6 at Jinhua in Southeastern China's province [83].

Table 5 gives average concentration of chemical species in snowfall samples. On average, equivalent concentration of ionic species followed the following order: $\mathrm{Ca}^{2+}>\mathrm{Cl}^{-}>$ 


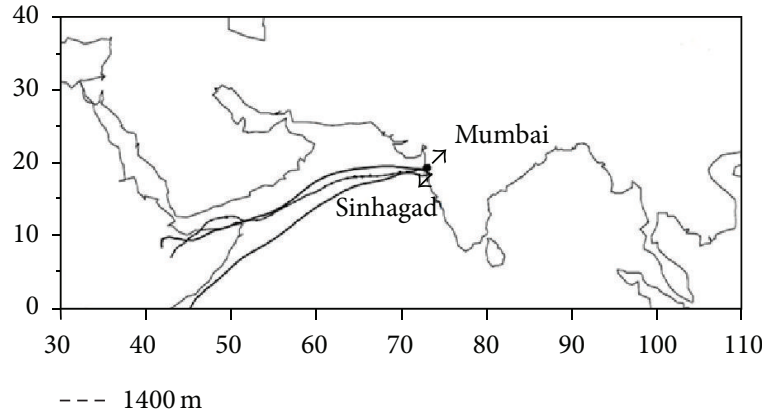

(a)

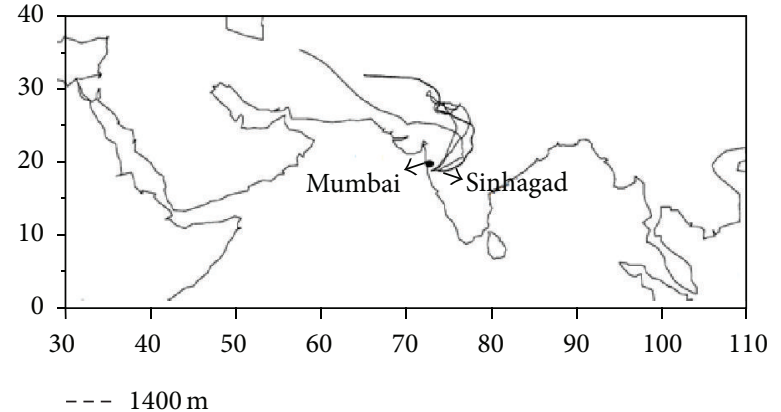

(b)

Figure 7: Seven-day back trajectories at Sinhagad during the (a) monsoon and (b) postmonsoon seasons of 2005 [40].

TABLE 5: Descriptive statistics of $\mathrm{pH}$ and major ions $\left(\mu \mathrm{eq} \mathrm{L}^{-1}\right)$ in snowmelt.

\begin{tabular}{lcccccccccccc}
\hline & $\mathrm{pH}$ & $\mathrm{Na}^{+}$ & $\mathrm{NH}_{4}^{+}$ & $\mathrm{K}^{+}$ & $\mathrm{Ca}^{2+}$ & $\mathrm{Mg}^{2+}$ & $\mathrm{F}^{-}$ & $\mathrm{Cl}^{-}$ & $\mathrm{NO}_{3}^{-}$ & $\mathrm{SO}_{4}^{2-}$ & $\mathrm{HCO}_{3}^{-}$ \\
\hline Average & 5.69 & 43.69 & 18.46 & 10.84 & 47.13 & 17.04 & 3.02 & 45.99 & 17.42 & 27.45 & 27.40 \\
s.d. & 0.6 & 23.5 & 10.8 & 5.7 & 21.1 & 7.9 & 2.3 & 25.3 & 7.3 & 8.3 & 17.7 \\
Min. & 4.75 & 7.51 & 4.23 & 2.99 & 17.65 & 0.10 & 0.08 & 10.75 & 5.43 & 11.95 & 1.72 \\
Max. & 6.98 & 93.56 & 39.41 & 21.55 & 96.44 & 35.31 & 7.02 & 106.51 & 31.11 & 46.73 & 71.91 \\
\hline
\end{tabular}

$\mathrm{Na}^{+}>\mathrm{SO}_{4}{ }^{2-}>\mathrm{HCO}_{3}{ }^{-}>\mathrm{NH}_{4}^{+}>\mathrm{NO}_{3}{ }^{-}>\mathrm{Mg}^{2+}>\mathrm{K}^{+}>$ $\mathrm{F}^{-}$. Very high concentration of $\mathrm{Ca}^{2+}$ among all ions at this site indicated the crustal dominance in snowfall samples at Kothi. The average concentration of $\mathrm{Ca}^{2+}$ was compared with others of snow and found to be higher than Mount Everest [84], Mt. Logan Massif [85], Khumbu-Himal, Nepal [86], but lower than Yulong snow Mt. [87] and Tien Shan [88]. In Indian region, many researchers have reported high concentration of $\mathrm{Ca}$ due to suspended soil dust in precipitation samples $[76,89,90]$. Since the site is situated at high altitude with less eroded soil [73], $\mathrm{Ca}^{2+}$ is not expected to be contributed by local soil significantly. As discussed above in the same section, the contribution of transported dust from African region, West India, and Nepal was significantly high at this site. Very high concentration of $\mathrm{SO}_{4}{ }^{2-}$ and $\mathrm{NO}_{3}{ }^{-}$might be due to its transport through Af, $\mathrm{ME}$, InW, and $\mathrm{Np}$ airmasses. The concentration of $\mathrm{SO}_{4}{ }^{2-}$ in snow samples at this site was lower than surface/fresh snow samples of Yulong snow Mt. [91], ice core samples of Dasuopu [92], and East Rongbuk [93], but lower than snow samples of Mt. Everest [84], Khumbu-Himal, Nepal [86], and Mt. Logan Massif [85]. Very similar range of concentration of $\mathrm{SO}_{4}{ }^{2-}$ has been reported by many workers in global precipitation due to fossil fuel combustion mainly $[55,73,80,82,89] . \mathrm{NO}_{3}{ }^{-}$concentration was found to be very high, which might be due to transport of $\mathrm{NO}_{x} / \mathrm{NO}_{3}{ }^{-}$from various airmasses as discussed above in the same section. Some contribution of $\mathrm{NO}_{3}{ }^{-}$from biomass burning during winter season to produce heat by local people cannot be ruled out. After $\mathrm{Ca}^{2+}$, very high concentration of $\mathrm{Cl}^{-}$and $\mathrm{Na}^{+}$among all ions indicated strong influences of marine components at this site and it is very clear from the above discussion. The high concentration of $\mathrm{NH}_{4}$ in snowfall samples might be due to its transport from African continents and Nepal mainly. Similarly, high concentration of K might be due to its transport of airmasses from Af, InW, and Np mainly.

\section{Conclusion}

Presently, computation of trajectories is highly advanced. Multiple and 3D trajectories are possible with numerous additional features, which make computation of backward, forward, and vertical motion very simple. However, there are uncertainties associated with the calculated trajectories and hence precaution of such errors is necessary for their meaningful interpretation. Nevertheless, the airmass trajectories are powerful tools for tracing pollution sources and the routes of transport. Transboundary pollution is becoming a serious issue in South Asia. Transport of pollutants from nearby countries as well as from far Europe, Middle East, and African continental regions to South Asia needs immediate attention of scientists and policy makers. Studies indicate that the net import and export of pollutants vary depending upon the season as the origin and path of airmasses change during different seasons and so the deposition load of different types of pollutants at the receptor sites. Hence, similar to CLRTAP, South Asian region also needs to develop a network to monitor the nature and type of pollutants and their quantification of annual import and export, followed by appropriate methods of assessment in relation to damage to human health, forests, and various agroecosystems. Airmass trajectories revealed that acidic pollutants from Europe and Middle East regions are deposited up to the remote Himalayan ranges via long range transport. Trajectory calculations provided very vital information about the continental transported emissions which were responsible for the elevated level of 
NOAA HYSPLIT model

Backward trajectory ending at 19:00 UTC 11 Dec 12

GDAS meteorological data

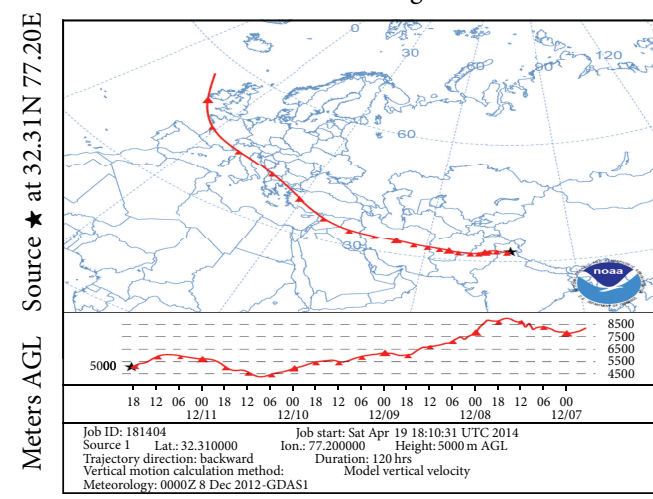

(a) $\mathrm{pH}=6.35(\mathrm{NAO})$

NOAA HYSPLIT model

Backward trajectory ending at 23:00 UTC 13 Dec 12

GDAS meteorological data

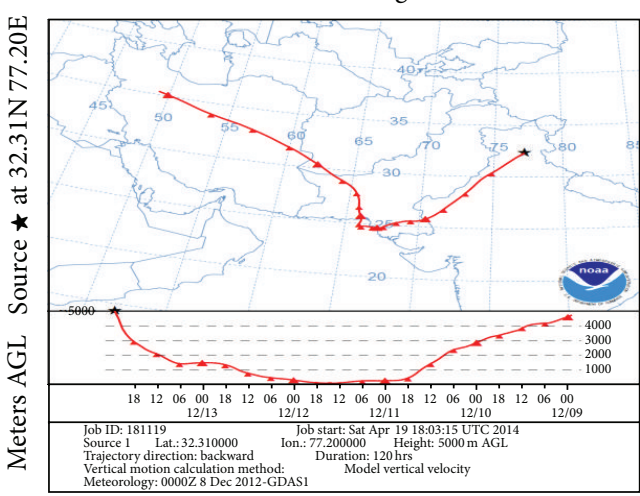

(c) $\mathrm{pH}=4.96(\mathrm{ME})$

NOAA HYSPLIT model

Backward trajectory ending at 11:00 UTC 24 Mar 13

GDAS meteorological data

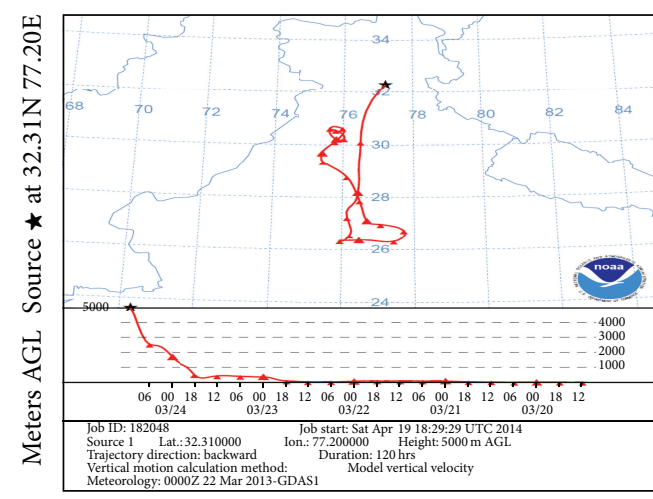

(e) $\mathrm{pH}=6.73(\mathrm{InW})$
NOAA HYSPLIT model

Backward trajectory ending at 11:00 UTC 23 Feb 13

GDAS meteorological data

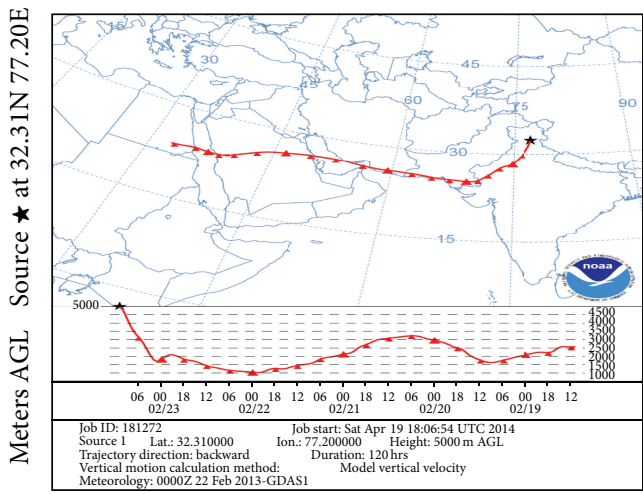

(b) $\mathrm{pH}=5.72(\mathrm{Af})$

NOAA HYSPLIT model

Backward trajectory ending at 11:00 UTC 29 Nov 12

GDAS meteorological data

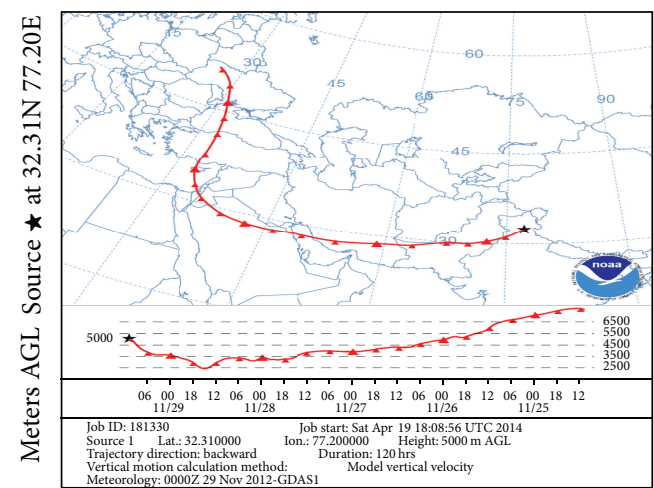

(d) $\mathrm{pH}=5.48(\mathrm{Eu})$

NOAA HYSPLIT model

Backward trajectory ending at 11:00 UTC 26 Feb 13 GDAS meteorological data

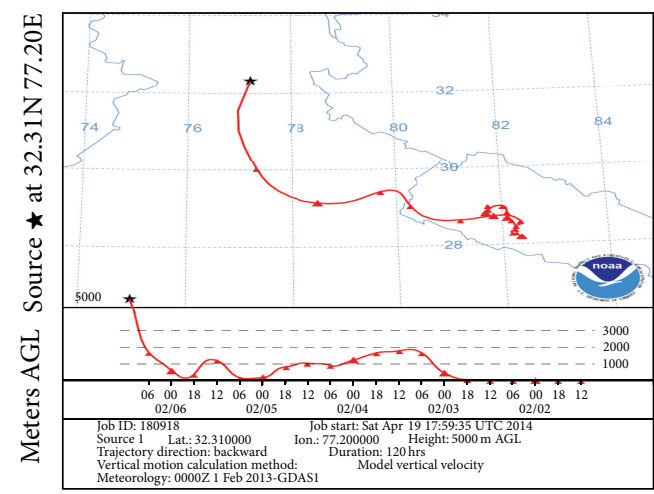

(f) $\mathrm{pH}=6.01(\mathrm{~Np})$

FIGURE 8: Typical examples of six different airmass trajectories arriving at the site. NAO = North Atlantic Ocean origin, Af $=$ African origin, $\mathrm{ME}=$ Middle East origin, $\mathrm{Eu}=$ European origin $(\mathrm{Eu}), \mathrm{InW}=$ Western India origin, and $\mathrm{Np}=$ Nepal origin. 


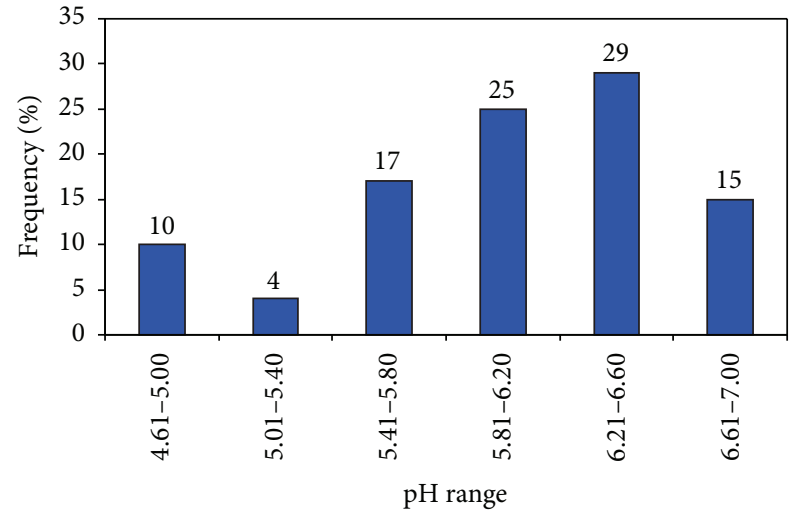

Figure 9: Percent frequency distribution of $\mathrm{pH}$ of snowmelt for whole dataset.

acidity of rain water at an ecosensitive site in Western Ghats in Southwest India.

\section{Conflict of Interests}

The authors declare that they have no conflict of interests regarding the publication of this paper.

\section{Acknowledgments}

Support of DST-PURSE and UGC India is gratefully acknowledged.

\section{References}

[1] J. A. Dutton, The Ceaseless Wind: An Introduction to the Theory of Atmospheric Motion, Dover, New York, NY, USA, 1986.

[2] H. R. Byers, General Meteorology, McGraw-Hill, New York, U.S.A, 4th edition, 1974

[3] D. J. Thomson and J. D. Wilson, History of Lagrangian Stochastic Models for Turbulent Dispersion, Langrangian Model of the Atmosphere, Geographical Monograph Series 200, American Geophhysical union, 2012.

[4] K. J. Davis, D. H. Lenschow, S. P. Oncley et al., "Role of entrainment in surface-atmosphere interactions over the boreal forest," Journal of Geophysical Research D, vol. 102, no. 24, pp. 29219-29230, 1997.

[5] P. Seibert, "Inverse modelling with a lagrangian particle dispersion model: application to point releases over limited time intervals in: air pollution modeling and its application," Journal of Applied Meteorology, vol. 14, pp. 381-389, 2004.

[6] A. Eliassen, J. Saltbones, F. Stordal, O. Hov, and I. S. A. Isaksen, "A Lagrangian long-range transport model with atmospheric boundary layer chemistry," Journal of Applied Meteorology, vol. 21, no. 11, pp. 1645-1661, 1982.

[7] D. Simpson, "Photochemical model calculations over Europe for two extended summer periods: 1985 and 1989. Model results and comparison with observations," Atmospheric Environment A, vol. 27, no. 6, pp. 921-943, 1993.

[8] S. Petterssen, "Weather analysis and forecasting," pp. 221-223, 1940.
[9] E. F. Danielsen and R. Bleck, "Research in four-dimensional diagnosis of cyclonic storm cloud system," AFCRL Rep. 67-0617, Bedford, Mass, USA, 1967, Available as, NTIS AD-670 847, from National Technical Information Service, Springfield, Va, USA.

[10] H. Rodhe, "A study of the sulfur budget for the atmosphere over Northern Europe," Tellus, vol. 24, pp. 128-138, 1972.

[11] T. D. Fox and J. D. Ludwick, "Lead (Pb) concentrations associated with 1000-MB geostrophic back trajectories at Quillayute, Washington," Atmospheric Environment, vol. 10, no. 10, pp. 799803, 1976.

[12] L. L. Ashbaugh, W. C. Malm, and W. Z. Sadeh, "A residence time probability analysis of sulfur concentrations at Grand Canyon National Park," Atmospheric Environment, vol. 19, no. 8, pp. 1263-1270, 1985

[13] A. V. Polissar, P. K. Hopke, P. Paatero et al., "The aerosol at Barrow, Alaska: long-term trends and source locations," Atmospheric Environment, vol. 33, no. 16, pp. 2441-2458, 1999.

[14] A. Stohl, "Computation, accuracy and applications of trajectories-a review and bibliography," Atmospheric Environment, vol. 32, no. 6, pp. 947-966, 1998.

[15] Z. L. Fleming, P. S. Monks, and A. J. Manning, "Review: untangling the influence of air-mass history in interpreting observed atmospheric composition," Atmospheric Research, vol. 104-105, pp. 1-39, 2012.

[16] B. F. Taubman, J. C. Hains, A. M. Thompson et al., "Aircraft vertical profiles of trace gas and aerosol pollution over the mid-Atlantic United States: Statistics and meteorological cluster analysis," Journal of Geophysical Research D: Atmospheres, vol. 111, no. 10, 2006.

[17] M. Cabello, J. A. G. Orza, V. Galiano, and G. Ruiz, "Influence of meteorological input data on backtrajectory cluster analysis a seven-year study for southeastern Spain," Advances in Science and Research, vol. 2, pp. 65-70, 2008.

[18] S. Pettersen, Weather Analysis and Forecasting: Motion and Motion Systems, vol. 1, McGraw-Hill, 1956.

[19] J. D. Kahl, "A cautionary note on the use of air trajectories in interpreting atmospheric chemistry measurements," Atmospheric Environment, vol. 27, no. 17-18, pp. 3037-3038, 1993.

[20] P. Seibert, "Convergence and accuracy of numerical methods for trajectory calculations," Journal of Applied Meteorology, vol. 32, no. 3, pp. 558-566, 1993.

[21] E. Isaacson and H. B. Keller, Analysis of Numerical Methods, vol. 541, John Wiley \& Sons, New York, NY. USA, 1966.

[22] P. Brumer, "Stability concepts in the numerical solution of classical atomic and molecular scattering problems," Journal of Computational Physics, vol. 14, pp. 391-419, 1974.

[23] J. T. Merrill, "Isentropic air-flow probability analysis," Journal of Geophysical Research: Atmospheres, vol. 99, pp. 25881-25889, 1994.

[24] A. Stohl, G. Wotawa, P. Seibert, and H. Kromp-Kolb, "Interpolation errors in wind fields as a function of spatial and temporal resolution and their impact on different types of kinematic trajectories," Journal of Applied Meteorology, vol. 34, no. 10, pp. 2149-2165, 1995.

[25] A. Virkkula, M. Aurela, R. Hillamo et al., "Chemical composition of atmospheric aerosol in the European subarctic: contribution of the Kola Peninsula smelter areas, central Europe, and the Arctic Ocean," Journal of Geophysical Research D: Atmospheres, vol. 104, no. 19, pp. 23681-23696, 1999.

[26] J. N. Cape, J. Methven, and L. E. Hudson, "The use of trajectory cluster analysis to interpret trace gas measurements at Mace 
Head, Ireland," Atmospheric Environment, vol. 34, no. 22, pp. 3651-3663, 2000.

[27] R. R. Draxler and G. D. Rolph, "HYSPLIT ( HYbrid SingleParticle Lagrangian Integrated Trajectory) Model. NOAA Air Resources Laboratory," Silver Spring, Md, USA, 2003, http://ready.arl.noaa.gov/HYSPLIT.php.

[28] P. Pochanart, H. Akimoto, Y. Kajii, V. M. Potemkin, and T. V. Khodzher, "Regional background ozone and carbon monoxide variations nin remote Siberia/East Asia," Journal of Geophysical Research D: Atmospheres, vol. 108, no. 1, pp. 1-18, 2003.

[29] B. A. Schichtel, K. A. Gebhart, M. G. Barna, and W. C. Malm, "Association of airmass transport patterns and particulate sulfur concentrations at Big Bend National Park, Texas," Atmospheric Environment, vol. 40, no. 5, pp. 992-1006, 2006.

[30] A. W. Delcloo and H. de Backer, "Five day 3D back trajectory clusters and trends analysis of the Uccle ozone sounding time series in the lower troposphere (1969-2001)," Atmospheric Environment, vol. 42, no. 19, pp. 4419-4432, 2008.

[31] G. Doğan, G. Güllü, and G. Tuncel, "Sources and source regions effecting the aerosol composition of the Eastern Mediterranean," Microchemical Journal, vol. 88, no. 2, pp. 142-149, 2008.

[32] O. A. Tarasova, I. A. Senik, M. G. Sosonkin, J. Cui, J. Staehelin, and A. S. H. Prévôt, "Surface ozone at the Caucasian site Kislovodsk High Mountain Station and the Swiss Alpine site Jungfraujoch: data analysis and trends (1990-2006)," Atmospheric Chemistry and Physics, vol. 9, no. 12, pp. 4157-4175, 2009.

[33] http://lagrange.empa.ch/lm_traj.html.

[34] H. Riede, P. Jockel, and R. Sander, "Quantifying atmospheric transport, chemistry, and mixing using a new trajectory-box model and a global atmospheric-chemistry GCM," Geoscience Model Development, vol. 2, pp. 267-280, 2009.

[35] R. P. Shadbolt, E. A. Waller, J. P. Messina, and J. A. Winkler, "Source regions of lower-tropospheric airflow trajectories for the lower peninsula of Michigan: a 40-year air mass climatology," Journal of Geophysical Research D: Atmospheres, vol. 111, no. 21, Article ID D21117, 2006.

[36] A. Riccio, G. Giunta, and E. Chianese, "The application of a trajectory classification procedure to interpret air pollution measurements in the urban area of Naples (Southern Italy)," Science of the Total Environment, vol. 376, no. 1-3, pp. 198-214, 2007.

[37] B. S. K. Reddy, K. R. Kumar, G. Balakrishnaiah et al., “Observational studies on the variations in surface ozone concentration at Anantapur in southern India," Atmospheric Research, vol. 98, no. 1, pp. 125-139, 2010.

[38] B. A. Begum, S. K. Biswas, G. G. Pandit et al., "Long-range transport of soil dust and smoke pollution in the South Asian region," Atmospheric Pollution Research, vol. 2, no. 2, pp. 151-157, 2011.

[39] A. H. M. Saadat, Md. M. Rahman, S. M. K. Hasan, and A. T. M. Jahangir Alam, "Travelling and source point identification of some transboundary air pollutants by trajectory analysis in Sathkhira, Bangladesh," Canadian Chemical Transactions, vol. 1, no. 1, pp. 56-65, 2013.

[40] K. B. Budhavant, P. S. P. Rao, P. D. Safai, and K. Ah, "Chemistry of monsoon and post-monsoon rains at a high altitude location, Sinhagad, India," Aerosol and Air Quality Research, vol. 9, no. 1, pp. 65-79, 2009.

[41] K. B. Budhavant, P. S. P. Rao, P. D. Safai, L. Granat, and H. Rodhe, "Chemical composition of the inorganic fraction of cloudwater at a high altitude station in West India," Atmospheric Environment, vol. 88, pp. 59-65, 2014.
[42] R. R. Draxler and A. D. Taylor, "Horizontal parameters for longrange transport modeling," Journal of Applied Meteorology, vol. 21, no. 3, pp. 367-372, 1982.

[43] J. C. Lin, C. Gerbig, S. C. Wofsy et al., "Measuring fluxes of trace gases at regional scales by Lagrangian observations: application to the $\mathrm{CO}_{2}$ Budget and Rectification Airborne (COBRA) study," Journal of Geophysical Research: Atmospheres, vol. 109, no. D15, 2004.

[44] D. Wen, J. C. Lin, D. B. Millet, A. F. Stein, and R. R. Draxler, "A backward-time stochastic Lagrangian air quality model," Atmospheric Environment, vol. 54, pp. 373-386, 2012.

[45] J. L. Moody, J. A. Galusky, and J. N. Galloway, "The use of atmospheric transport pattern recognition techniques in understanding variation in precipitation chemistry," in Atmospheric Deposition (Proceedings of the Baltimore Symposium, May 1989), IAHS Publ. No. 179, May 1989.

[46] M. Escudero, A. F. Stein, R. R. Draxler et al., "Source apportionment for African dust outbreaks over the Western Mediterranean using the HYSPLIT model," Atmospheric Research, vol. 99, no. 3-4, pp. 518-527, 2011.

[47] J. Baker, "A cluster analysis of long range air transport pathways and associated pollutant concentrations within the UK," Atmospheric Environment, vol. 44, no. 4, pp. 563-571, 2010.

[48] K. A. Gebhart, B. A. Schichtel, W. C. Malm, M. G. Barna, M. A. Rodriguez, and J. L. Collett, "Back-trajectory-based source apportionment of airborne sulfur and nitrogen concentrations at Rocky Mountain National Park, Colorado, USA," Atmospheric Environment, vol. 45, no. 3, pp. 621-633, 2011.

[49] B. de Foy, M. Zavala, N. Bei, and L. T. Molina, "Evaluation of WRF mesoscale simulations and particle trajectory analysis for the MILAGRO field campaign," Atmospheric Chemistry and Physics, vol. 9, no. 13, pp. 4419-4438, 2009.

[50] R. M. Harrison, J. L. Grenfell, J. D. Peak et al., "Influence of airmass back trajectory upon nitrogen compound composition," Atmospheric Environment, vol. 34, no. 10, pp. 1519-1527, 2000.

[51] T. W. Chan and M. Mozurkewich, "Application of absolute principal component analysis to size distribution data: identification of particle origins," Atmospheric Chemistry and Physics, vol. 7, no. 3, pp. 887-897, 2007.

[52] L. A. K. Reddy, U. C. Kulshrestha, J. Satyanarayana, M. J. Kulshrestha, and K. K. Moorthy, "Chemical characteristics of PM10 aerosols and airmass trajectories over Bay of Bengal and Arabian Sea during ICARB," Journal of Earth System Science, vol. 117, no. 1, pp. 345-352, 2008.

[53] P. Salvador, B. Artíñano, X. Querol, and A. Alastuey, "A combined analysis of backward trajectories and aerosol chemistry to characterise long-range transport episodes of particulate matter: the Madrid air basin, a case study," Science of the Total Environment, vol. 390, no. 2-3, pp. 495-506, 2008.

[54] L. Granat, M. Norman, C. Leck, U. C. Kulshrestha, and $\mathrm{H}$. Rodhe, "Wet scavenging of sulfur compounds and other constituents during the Indian Ocean Experiment (INDOEX)," Journal of Geophysical Research D: Atmospheres, vol. 107, no. 19, article 8025, 2002.

[55] J. Satyanarayana, L. A. K. Reddy, M. J. Kulshrestha, R. N. Rao, and U. C. Kulshrestha, "Chemical composition of rain water and influence of airmass trajectories at a rural site in an ecological sensitive area of Western Ghats (India)," Journal of Atmospheric Chemistry, vol. 66, no. 3, pp. 101-116, 2010.

[56] A. Dvorská, G. Lammel, and I. Holoubek, "Recent trends of persistent organic pollutants in air in central Europe-air 
monitoring in combination with air mass trajectory statistics as a tool to study the effectivity of regional chemical policy," Atmospheric Environment, vol. 43, no. 6, pp. 1280-1287, 2009.

[57] D. W. Tarasick, J. J. Jin, V. E. Fioletov et al., "High-resolution tropospheric ozone fields for INTEX and ARCTAS from IONS ozonesondes," Journal of Geophysical Research D, vol. 115, no. 20, Article ID D20301, 2010.

[58] A. S. Lefohn, H. Wernli, D. Shadwick, S. Limbach, S. J. Oltmans, and M. Shapiro, "The importance of stratospheric-tropospheric transport in affecting surface ozone concentrations in the Western and Northern tier of the United States," Atmospheric Environment, vol. 45, no. 28, pp. 4845-4857, 2011.

[59] P. D. Tyson, M. Garstang, R. J. Swap, E. V. Browell, R. D. Diab, and A. M. Thompson, "Transport and Vertical structure of ozone and aerosol distributions over southern Africa," in Biomass Burning and Global Change, J. S. Levine, Ed., pp. 403421, MIT Press, Cambridge, UK, 1996.

[60] K. Ashrafi, M. Shafiepour-Motlagh, A. Aslemand, and S. Ghade, "Dust storm simulation over Iran using HYSPLIT," Journal of Environmental Health Science and Engineering, vol. 12, no. 1, article 9, 2014.

[61] K. K. Moorthy, A. Saha, B. S. N. Prasad, K. Niranjan, D. Jhurry, and P. S. Pillai, "Aerosol optical depths over peninsular India and adjoining oceans during the INDOEX campaigns: spatial, temporal, and spectral characteristics," Journal of Geophysical Research D: Atmospheres, vol. 106, no. 22, pp. 28539-28554, 2001.

[62] A. Iqbal and N. T. K. Oanh, "Assessment of acid deposition over Dhaka division using CAMx-MM5 modeling system," Atmospheric Pollution Research, vol. 2, no. 4, pp. 452-462, 2011.

[63] M. Norman, S. N. Das, A. G. Pillai, L. Granat, and H. Rodhe, "Influence of air mass trajectories on the chemical composition of precipitation in India," Atmospheric Environment, vol. 35, no. 25, pp. 4223-4235, 2001.

[64] B. Kumar, G. P. Gupta, S. Singh, and U. C. Kulshrestha, "Chemical characterization of snowfall in western Himalayan region of India," Unpublished data.

[65] F. Li and V. Ramanathan, "Winter to summer monsoon variation of aerosol optical depth over the tropical Indian Ocean," Journal of Geophysical Research D: Atmospheres, vol. 107, no. 16, pp. 2-13, 2002.

[66] T. N. Krishnamurti, B. Jha, J. Prospero, A. Jayaraman, and V. Ramanathan, "Aerosol and pollutant transport and their impact on radiative forcing over the tropical Indian Ocean during the January-February 1996 pre-INDOEX cruise," Tellus, vol. 50, no. 5, pp. 521-542, 1998.

[67] S. Verma, C. Venkataraman, O. Boucher, and S. Ramachandran, "Source evaluation of aerosols measured during the Indian Ocean Experiment using combined chemical transport and back trajectory modeling," Journal of Geophysical Research D: Atmospheres, vol. 112, no. 11, 2007.

[68] R. Das, L. Granat, C. Leck, P. S. Praveen, and H. Rodhe, "Chemical composition of rainwater at Maldives Climate Observatory at Hanimaadhoo (MCOH)," Atmospheric Chemistry and Physics, vol. 11, no. 8, pp. 3743-3755, 2011.

[69] K. Alam, S. Qureshi, and T. Blaschke, "Monitoring spatiotemporal aerosol patterns over Pakistan based on MODIS, TOMS and MISR satellite data and a HYSPLIT model," Atmospheric Environment, vol. 45, no. 27, pp. 4641-4651, 2011.

[70] S. Singh, B. Kumar, G. P. Gupta, and U. C. Kulshrestha, "Signatures of increasing energy demand of past two decades as captured in rain water composition and airmass trajectory analysis at Delhi (India)," Atmospheric Environment. In press.
[71] A. Kumar, S. Tiwari, D. S. Bisht et al., "Aerosol characteristics during the coolest june month over new delhi, Northern India," International Journal of Remote Sensing, vol. 32, no. 23, pp. 8463-8483, 2011.

[72] LRTAP, http://www.unece.org/env/lrtap.

[73] S. Tiwari, D. M. Chate, D. S. Bisht, M. K. Srivastava, and B. Padmanabhamurty, "Rainwater chemistry in the North Western Himalayan Region, India," Atmospheric Research, vol. 104-105, pp. 128-138, 2012.

[74] M. S. Naik, L. T. Khemani, G. A. Momin, P. S. P. Rao, P. D. Safai, and A. G. Pillai, "Chemical composition of fresh snow from Gulmarg, North India," Environmental Pollution, vol. 87, no. 2, pp. 167-171, 1995.

[75] D. C. Parashar, L. Granat, U. C. Kulshrestha et al., "Chemical composition of precipitation in India and Nepal-apreliminary report on an Indo-Swedish project on atmospheric chemistry," Tech. Rep. CM90, IMI, Stockholm University, Stockholm, Sweden, 1996.

[76] U. C. Kulshrestha, A. K. Sarkar, S. S. Srivastava, and D. C. Parashar, "Investigation into atmospheric deposition through precipitation studies at New Delhi (India)," Atmospheric Environment, vol. 30, no. 24, pp. 4149-4154, 1996.

[77] U. C. Kulshrestha, L. Granat, M. Engardt, and H. Rodhe, "Review of precipitation monitoring studies in India-a search for regional patterns," Atmospheric Environment, vol. 39, no. 38, pp. 7403-7419, 2005.

[78] L. T. Khemani, G. A. Momin, P. S. Prakasa Rao, P. D. Safai, G. Singh, and R. K. Kapoor, "Spread of acid rain over India," Atmospheric Environment, vol. 23, no. 4, pp. 757-762, 1989.

[79] A. Saxena, S. Sharma, U. C. Kulshrestha, and S. S. Srivastava, "Factors affecting alkaline nature of rain water in Agra (India)," Environmental Pollution, vol. 74, no. 2, pp. 129-138, 1991.

[80] A. Avila and M. Alarcón, "Relationship between precipitation chemistry and meteorological situations at a rural site in Northeastern Spain," Atmospheric Environment, vol. 33, no. 11, pp. 1663-1677, 1999.

[81] R. Das, S. N. Das, and V. N. Misra, "Chemical composition of rainwater and dustfall at Bhubaneswar in the east coast of India," Atmospheric Environment, vol. 39, no. 32, pp. 5908-5916, 2005.

[82] K. B. Budhavant, P. S. P. Rao, P. D. Safai, and K. Ali, "Influence of local sources on rainwater chemistry over Pune region, India," Atmospheric Research, vol. 100, no. 1, pp. 121-131, 2011.

[83] M. Zhang, S. Wang, F. Wu, X. Yuan, and Y. Zhang, "Chemical compositions of wet precipitation and anthropogenic influences at a developing urban site in Southeastern China," Atmospheric Research, vol. 84, no. 4, pp. 311-322, 2007.

[84] S. C. Kang, P. A. Mayewski, D. H. Qin, S. A. Sneed, J. W. Ren, and D. Q. Zhang, "Seasonal differences in snow chemistry from the vicinity of Mt. Everest, central Himalayas," Atmospheric Environment, vol. 38, no. 18, pp. 2819-2829, 2004.

[85] K. Yalcin, C. P. Wake, S. Kang, K. J. Kreutz, and S. I. Whitlow, "Seasonal and spatial variability in snow chemistry at Eclipse Icefield, Yukon, Canada," Annals of Glaciology, vol. 43, pp. 230238, 2006.

[86] A. Marinoni, S. Polesello, C. Smiraglia, and S. Valsecchi, "Chemical composition of freshsnow samples from the southern slope of Mt. Everest region (Khumbu-Himal region, Nepal)," Atmospheric Environment, vol. 35, no. 18, pp. 3183-3190, 2001.

[87] H. Niu, Y. He, G. Zhu et al., "Environmental implications of the latest snow chemistry from Mt. Yulong, Southeastern Tibetan Plateau," Quaternary International, vol. 313-314, pp. 168-178, 2013. 
[88] K. J. Kreutz, V. B. Aizen, L. D. Cecil, and C. P. Wake, "Oxygen isotopic and soluble ionic composition of a shallow firn core, Inilchek glacier, central Tien Shan," Journal of Glaciology, vol. 47, no. 159, pp. 548-554, 2001.

[89] U. C. Kulshrestha, M. J. Kulshrestha, R. Sekar, G. S. R. Sastry, and M. Vairamani, "Chemical characteristics of rainwater at an urban site of south-central India," Atmospheric Environment, vol. 37, no. 21, pp. 3019-3026, 2003.

[90] M. Jain, U. C. Kulshrestha, A. K. Sarkar, and D. C. Parashar, "Influence of crustal aerosols on wet deposition at urban and rural sites in India," Atmospheric Environment, vol. 34, no. 2930, pp. 5129-5137, 2000.

[91] G. Zhu, T. Pu, Y. He, P. Shi, and T. Zhang, "Seasonal variations of major ions in fresh snow at Baishui Glacier No. 1, Yulong Mountain, China," Environmental Earth Sciences, vol. 69, no. 1, pp. 1-10, 2013.

[92] S. C. Kang, C. P. Wake, D. H. Qin, P. A. Mayewski, and T. D. Yao, "Monsoon and dust signals recorded in Dasuopu glacier, Tibetan Plateau," Journal of Glaciology, vol. 46, no. 153, pp. 222226, 2000.

[93] D. H. Qin, S. G. Hou, D. Q. Zhang et al., "Preliminary results from the chemical records of an $80.4 \mathrm{~m}$ ice core recovered from East Rongbuk Glacier, Qomolangma (Mount Everest), Himalaya," Annals of Glaciology, vol. 35, pp. 278-284, 2002. 

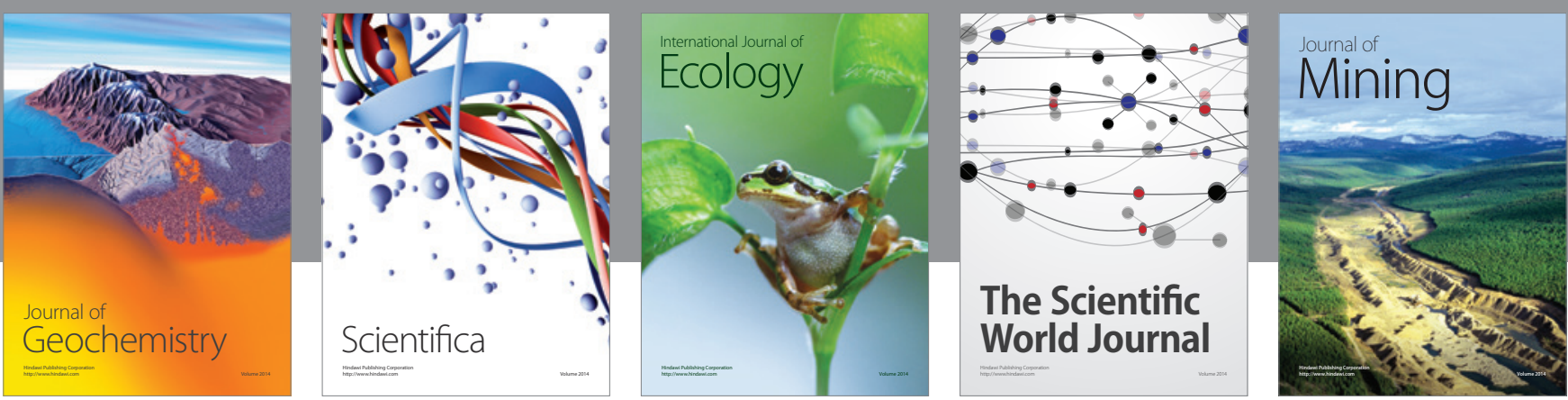

The Scientific World Journal
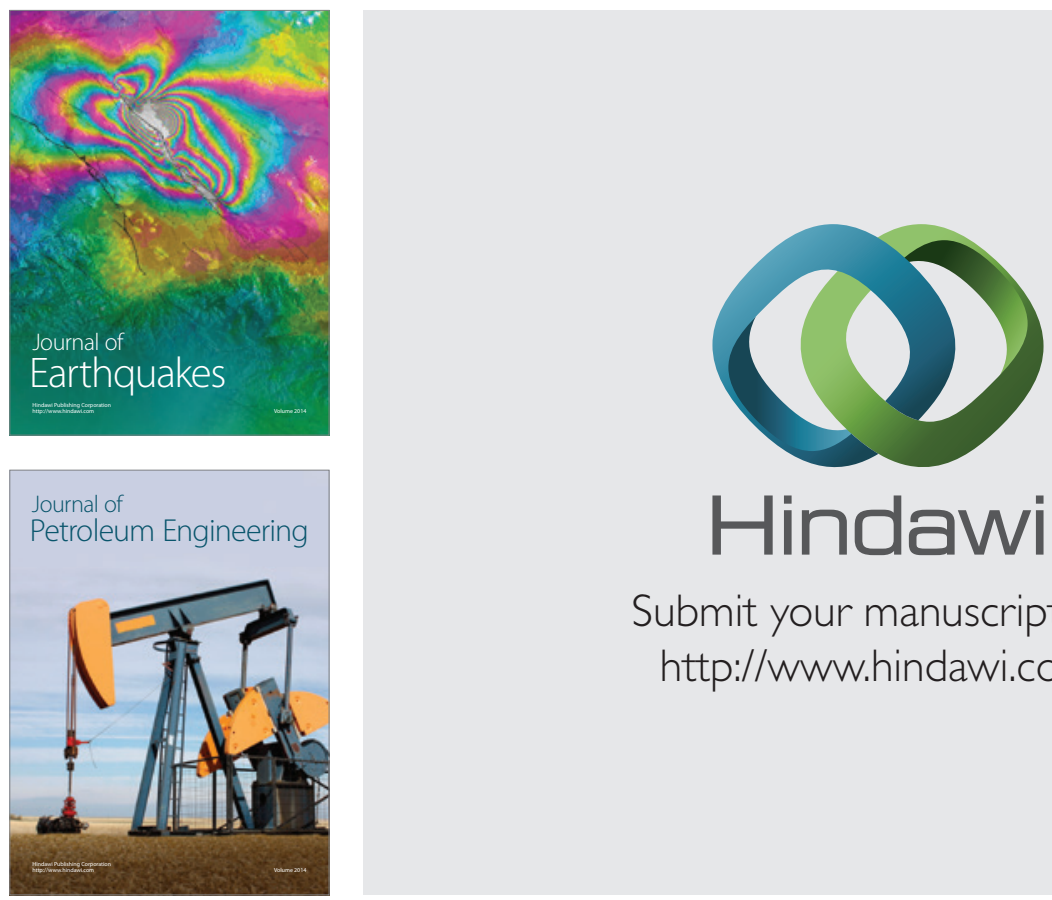

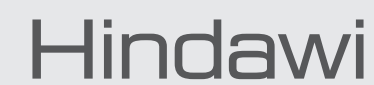

Submit your manuscripts at

http://www.hindawi.com
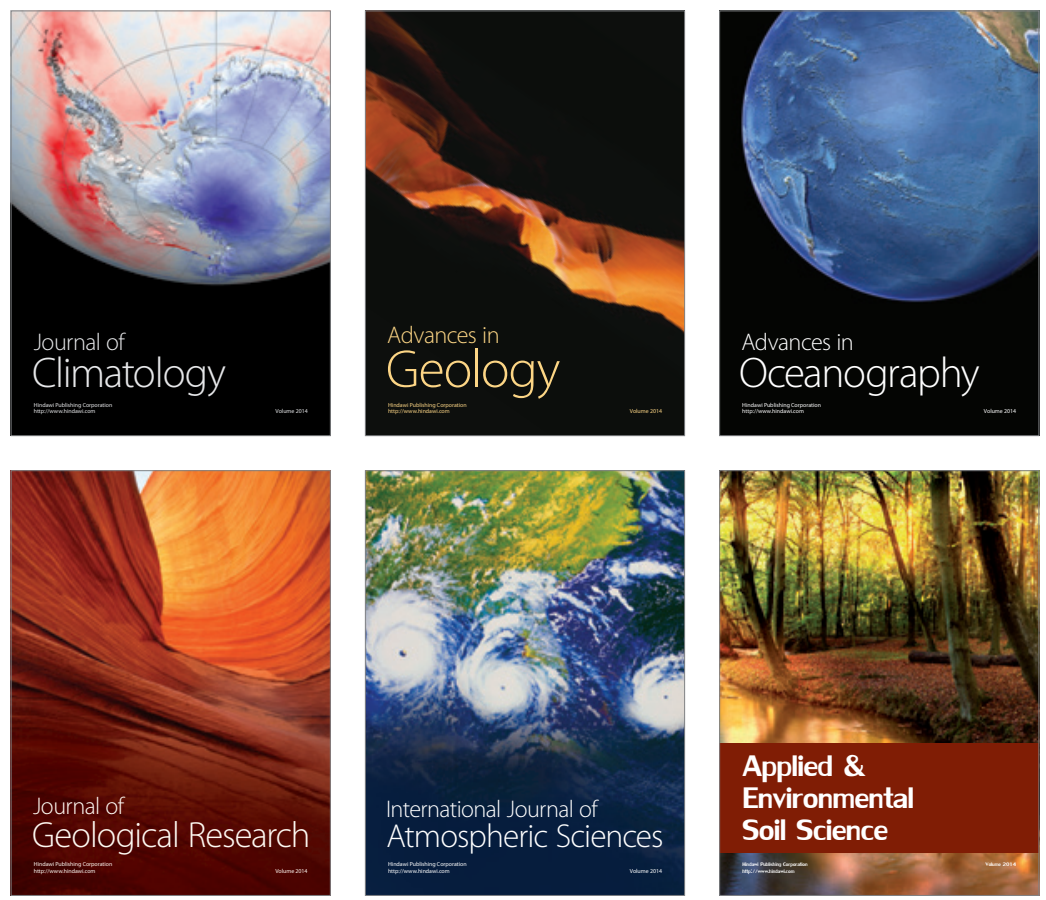
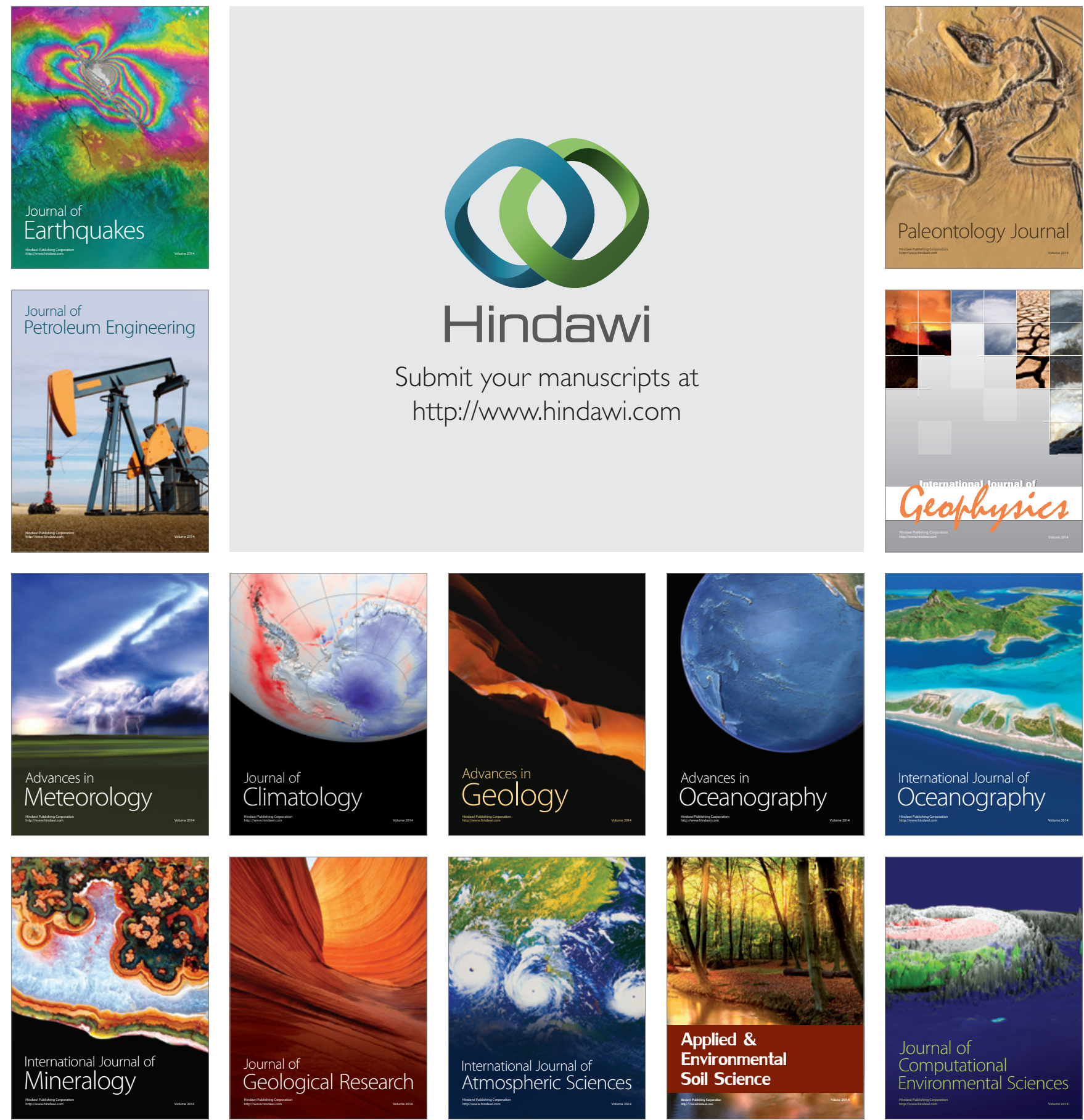